\title{
Primary production enhancement by artificial upwelling in a western Norwegian fjord
}

\author{
Jan Aure ${ }^{1}$, Øivind Strand ${ }^{1}$, Svein Rune Erga ${ }^{2}$, Tore Strohmeier ${ }^{1}$ \\ ${ }^{1}$ Institute of Marine Research, Nordnesgaten 50, 5817 Bergen, Norway \\ ${ }^{2}$ Department of Biology, University of Bergen, Jahnebakken 5, 5020 Bergen, Norway
}

\begin{abstract}
To enhance primary production rate for shellfish cultivation in fjords, a large-scale artificial upwelling experiment was carried out in a western Norwegian fjord during the summers of 2004 and 2005. Pumping $2 \mathrm{~m}^{3} \mathrm{~s}^{-1}$ brackish surface water to a depth of $30 \mathrm{~m}$ created an artificial upwelling of nutrient-rich deeper water. The entrainment of deeper water into the buoyant brackish plume resulted in a transport of about $450 \mathrm{~kg} \mathrm{~d}^{-1}$ nitrate, $760 \mathrm{~kg} \mathrm{~d}^{-1}$ silicate and $75 \mathrm{~kg} \mathrm{~d}^{-1}$ phosphate to an intrusion depth of 8 to $10 \mathrm{~m}$. The artificial upwelling approximately tripled mean chlorophyll $a$ (chl a) concentration and related primary production rate during the summer within an influence area of $10 \mathrm{~km}^{2}$ near the head of the fjord. The size of the area of influence and the relative increase of the algae biomass within it depend on both the water exchange and the photosynthetic effectiveness. The relatively high silicate content of the deeper water stimulated diatom growth inside the area influenced by the artificial upwelling. A higher stable level of phytoplankton biomass, dominated by nontoxic species, would probably increase the carrying capacity of seston-feeding shellfish and could form the basis of more predictable mussel cultivation in fjords.
\end{abstract}

KEY WORDS: Artificial upwelling $\cdot$ Phytoplankton biomass $\cdot$ Primary production rate $\cdot$ Fjord Mussel culture Resale or republication not permitted without written consent of the publisher

\section{INTRODUCTION}

Physical processes regulating the vertical structure of the ocean determine marine productivity, as exemplified by the importance of coastal upwelling systems in global fisheries (Ryther 1969). In many coastal waters primary production rates benefit from upwelling of deep water. In this process surface waters are displaced offshore by a one-sided horizontal divergence caused by surface Ekman transport and are replaced by nutrient-rich deep water (Smith et al. 1983). The upwelling circulation operates on a wide range of time scales, which include short (hours), intermediate (days) and long (seasonal and inter-annual) scales. The large-scale coastal upwelling regions are among the most productive in the world, with annual primary production rates of more than $700 \mathrm{~g} \mathrm{C} \mathrm{m}^{-2} \mathrm{yr}^{-1}$ (Mann \& Lazier 1996). These systems favour growth of diatoms. Coastal upwelling also supports some of the most productive and successful mussel farming areas
(Pitcher \& Calder 1998, Figueiras et al. 2000). Typical annual primary production rates in Norwegian fjords and coastal waters are 110 to $140 \mathrm{~g} \mathrm{C} \mathrm{m}^{-2} \mathrm{yr}^{-1}$ (Eilertsen \& Taasen 1984, Erga \& Heimdal 1984, Erga 1989b, Erga et al. 2005), where about $60 \%$ takes place after the spring bloom during March and April.

In summer fjords are stratified primarily as a result of freshwater runoff and calm wind conditions that restrict vertical mixing of nutrients into the euphotic layer (Aure et al. 1996, Asplin et al. 1999). Nutrients derived from freshwater runoff, or intermediate water inflow from the outer fjord or coastal waters, are generally less important than the vertical nutrient flux (Aksnes et al. 1989). Consequently, the euphotic zone is nutrient-depleted during summer and the primary production rates, which are mainly based on nutrients regenerated in the water column (Skjoldal et al. 2004), are typically reduced to one-third of spring bloom levels (Erga et al. 2005). Primary production rate based upon new nutrients (e.g. an upward nutrient flux from 
deeper waters or supported by drainage from the land) is called 'new production' and primary production rate based upon regenerated nutrients in the upper mixed layer is called 'regenerated production' (Dugdale \& Goering 1967, Paasche 1988). Total production is the sum of new production and regenerated production. Wassmann (1990) found that total production was about 2.5 times as high as new production in south Norwegian coastal and fjord waters. For the summer upwelling events on the Iberian shelf, northwest Spain, a mean R-value of 2.8 was found (Joint et al. 2002).

The Norwegian research programme MARICULT (1996 to 2000) aimed to provide a basis for the evaluation of environmental constraints and the potential for greater supplies of food, raw materials and energy from the ocean (Olsen 2002). One of the research topics in this programme was enhancement of the production potential in fjords by the creation of artificial upwelling systems. There are a number of simulated or small-scale enrichment experiments using deep water, and it has been proposed to use artificial upwelling in enclosed fjord areas to develop safe production of toxin-free, high-quality shellfish (Aksnes et al. 1985, Berntsen et al. 2002, Olsen 2002). The possibility of moving shellfish into such areas for quality enhancement (increased meat content) and toxicity treatment has also been considered. To the best of our knowledge, the first full-scale experiment on artificial upwelling in coastal waters was carried out in Japan, where concrete panels were installed on the sea bottom to divert deep water (40 to $50 \mathrm{~m}$ ) into the euphotic zone of the water column (Morikawa 2001). A significant enhancement of phytoplankton and zooplankton production was obtained.

On the basis of the results from observations and models simulating upwelling scenarios (Aure et al. 2000, Berntsen et al. 2002, McClimans et al. 2002), the MARICULT programme recommended further work to validate these results at a fjord-scale testing site to determine the potential of artificial upwelling of deeper nutrient-rich seawater in mariculture applications. Using a numerical buoyant flume model and laboratory simulations, McClimans et al. (2002) demonstrated the effectiveness of a submerged discharge of freshwater to force vertical transport of nutrient-rich deep water to the euphotic zone in fjords. Berntsen et al. (2002) employed a coupled physical-chemical-biological model to study primary production rate in an idealized $60 \mathrm{~km}$ long, $4 \mathrm{~km}$ wide fjord subjected to various submerged freshwater discharge scenarios. They concluded that primary production rate could be enhanced by a factor of 3. Due to the higher silicate content of the deeper water, the artificial upwelling tends to stimulate diatom more than flagellate growth
(Egge \& Aksnes 1992), thereby reducing the problem in fjords of diarrhetic shellfish toxin (DST) caused by Dinophysis spp. (Aune et al. 1996). In view of these results the inner part of Lysefjord in western Norway was selected to be suitable for a large scale experiment, since stratification persists throughout the summer and early autumn months. Conditions there provide sufficient quantities of brackish surface water, easily accessible nutrient-rich deeper water and limited water exchange with the open fjord system. We present the results of our first attempt to perform a large- scale experiment aimed to determine the potential impacts of artificial upwelling on phytoplankton biomass, production and composition.

\section{MATERIALS AND METHODS}

Study site. The Lysefjord is located on the southwest coast of Norway $\left(59^{\circ} 0^{\prime} \mathrm{N}, 6^{\circ} 16^{\prime} \mathrm{E}\right)$ (Fig. 1). The fjord is approximately $40 \mathrm{~km}$ long and 0.5 to $2 \mathrm{~km}$ wide. The sill depth is $14 \mathrm{~m}$, maximum depth is $460 \mathrm{~m}$ and the surface area is $44 \mathrm{~km}^{2}$. The mean tidal range is $0.4 \mathrm{~m}$ and the freshwater supply to the Lysefjord varies between 40 and $90 \mathrm{~m}^{3} \mathrm{~s}^{-1}$, with the highest discharges occurring in May. Since hydropower plants became operational in 1935 and 1952, the mean freshwater input to the fjord during April through September has decreased by 30 to $40 \%$.

Forced upwelling. The artificial upwelling system is mounted on a moored platform located outside the freshwater discharge of a hydropower plant near the head of the Lysefjord (Fig. 1). Brackish water, taken from depths of between 0 and $3 \mathrm{~m}$, is forced down through a vertically mounted pipe by an electrical pump (ITT Flygt pump) (Fig. 2). The diameter of the pipe is $1.25 \mathrm{~m}$ and the pump power output of $60 \mathrm{~kW}$ produces a flow of about $2 \mathrm{~m}^{3} \mathrm{~s}^{-1}$ from the outlet at $30 \mathrm{~m}$ depth. Due to the buoyancy of the submerged brackish water it rises to the surface and mixes with the more saline and nutrient rich deeper water. The equilibrium depth $\left(Z_{\mathrm{o}}\right)$ is defined as the depth at which the density of the rising plume is equal to the density of the ambient water, and the intrusion depth $\left(Z_{\mathrm{i}}\right)$ is expected to be a few metres above $Z_{0}$ (McClimans et al. 2002). The mean mixing rate of the brackish water and seawater and related intrusion level was estimated by adding fluorescein dye to the submerged brackish water.

Observations. Four sampling stations were set up within the main observation area $A_{o}$ (Stns 11, 16, 17 and 01) (Fig. 1). The surface area and average width of the fjord inside $A_{0}$ are $10 \mathrm{~km}^{2}$ and $1 \mathrm{~km}$, respectively. Outside this area we set up Stns 18, 02, 14 in the central and outer part of the fjord and Stn 03 in the Høgs- 


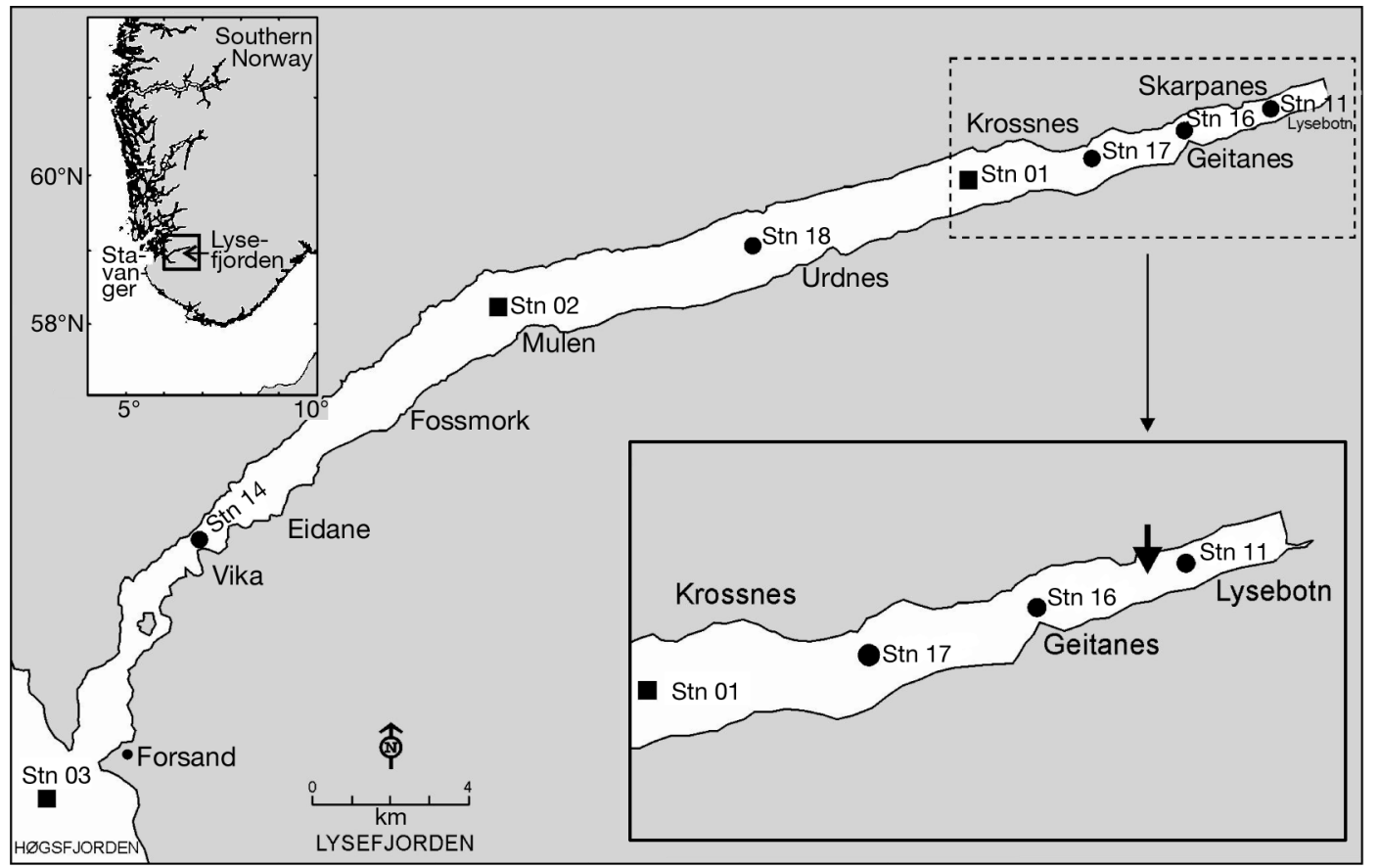

Fig. 1. The Lysefjord, located on the southwest coast of Norway, showing the positions of sampling stations. The enlarged map shows the main observation area $A_{o}\left(10 \mathrm{~km}^{2}\right)$. The arrow between Stns 11 and 16 indicates the location of the anchored artificial upwelling platform

fjord outside the Lysefjord. The artificial upwelling experiments were executed during the periods 19 May to 24 August 2004 and 18 June to 27 August 2005.

Measurements of temperature, salinity, in situ fluorescence and turbidity were made and samples of phytoplankton were gathered weekly from May to June and from late July to September in 2004, and from June to September in 2005. On three 5-d cruises (May/June, August and September) in 2004 and 2005, additional samples were taken for analyses of inorganic nutrients (nitrate, nitrite, phosphate and silicate), particulate organic carbon (POC) and chlorophyll $a$ (chl a). To examine the time-scale of the phytoplankton response to the increased supply of nutrients to the euphotic layer, daily observations were carried out

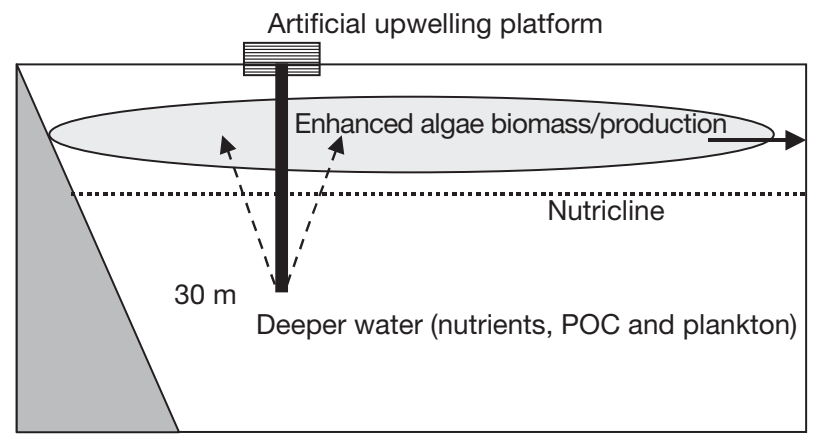

Fig. 2. Relative position of the anchored artificial upwelling system in the water column in the Lysefjord between 18 and 27 June 2005. Measurements of temperature, salinity, in situ fluorescence, turbidity and nutrients on selected stations were also conducted in the Lysefjord in August 2002, and in the period June to September 2003 ( 7 dates) and 2006 (10 dates). Samples for chl a analysis were filtered onto GF/F filters and stored at $-20^{\circ} \mathrm{C}$. The samples were analysed fluorometrically (Turner Designs-10) according to Parsons et al. (1992) using 90\% acetone as solvent and acid corrections for phaeopigments. The fluorometer was calibrated with known concentrations of Sigma chl a (Sigma Chemicals) measured spectrophotometrically. Fluorescence-chl a (FC), turbidity (Seapoint type), salinity and temperature were measured by a CTD (SD $200 \mathrm{~W}$, SAIV A/S). Measurements were recorded every second while the CTD was lowered at a rate of $<0.5 \mathrm{~m} \mathrm{~s}^{-1}$ from the surface to $30-50 \mathrm{~m}$. The FC data were calibrated against $\mathrm{chl}$ a concentrations, and FC values were converted to chl $a$ using the equation $y=$ $0.9 x+0.25\left(r^{2}=0.75\right)$, where $y$ is chl $a$ and $x$ is measured FC. Particulate organic carbon was analysed in a Carlo-Erba analyser. Dissolved inorganic nutrients were analysed according to standard methods (Parsons et al. 1992) adapted for an auto-analyser. Primary production rate, measured as carbon assimilation rates, was obtained from $24 \mathrm{~h}$ in situ incubations at Stns 17 and 03 , starting in the afternoon on 22 June and 24 June 2005, respectively. They were conducted in accordance with the ${ }^{14} \mathrm{C}$-method (Steemann Nielsen 
1952). Phytoplankton abundance was determined according to Utermöhl (1931) using neutralized formalin and Lugol as preservative. Phytoplankton is expressed as biovolume (or plasma volume), i.e. cell volume minus vacuole volume.

Water currents were measured at depths of 5, 8, 10 and $15 \mathrm{~m}$ by current meters (SD6000, Sensor Data AS). Current direction and speed were recorded every 10 min at Stn 16 from 1 to 20 May and late July to September in 2004, and from June to September in 2005. Wind direction and speed were measured at the upwelling platform $5 \mathrm{~m}$ above sea level from 21 June to 18 August 2005. Subsurface irradiance in the visible part of the spectrum (PAR) was obtained with a PUV 500 from Biospherical Instruments at vertical profiles down to depths of 25 to $30 \mathrm{~m}$. Measurements were made at around local noon at Stns 02 and 03 between 22 and 24 June 2005.

\section{RESULTS}

\section{Physical conditions}

A typical vertical and horizontal salinity distribution of the upper $25 \mathrm{~m}$ of the inner part of the Lysefjord is represented by the measurements made on 22 July 2005 (Fig. 3). From May to September in 2004 and 2005 , the mean depth of the brackish layer (salinity < $25.0 \mathrm{psu})$ at $\mathrm{Stn} 11$ was $5.0 \mathrm{~m}(\mathrm{SD}=1.3, \mathrm{n}=18)$. Within the depth interval of 0 to $3 \mathrm{~m}$, where the pump takes its water, the mean salinity was $14.0 \mathrm{psu}(\mathrm{SD}=4.6, \mathrm{n}=18)$. Below the brackish layer salinity gradually increased to about $33.0 \mathrm{psu}$ at $30 \mathrm{~m}$ depth. From May to September temperatures gradually increased from 8.5 to $18.0^{\circ} \mathrm{C}$ in the brackish layer $(0$ to $5 \mathrm{~m}$ ), from 7.5 to $10.5^{\circ} \mathrm{C}$ at $10 \mathrm{~m}$ and from 7.0 to $8.5^{\circ} \mathrm{C}$ at $15 \mathrm{~m}$ depth.

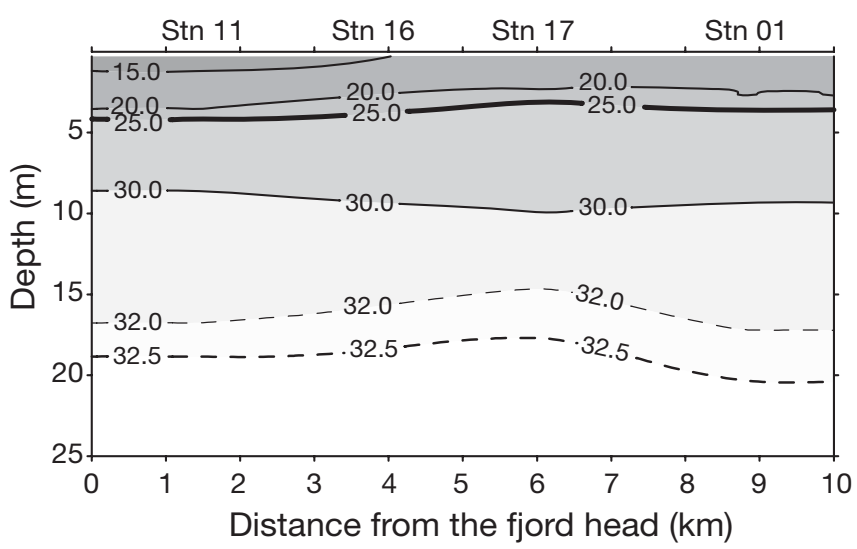

Fig. 3. Typical vertical distribution of salinity (psu) between 0 and $25 \mathrm{~m}$ depths in the inner $10 \mathrm{~km}$ of the Lysefjord in summer (22 July 2005)
In 2004 the residual currents ( $24 \mathrm{~h}$ running mean) at depths between 5 and $15 \mathrm{~m}$ at Geitaneset (Stn 16) were heading out of the fjord, except at the $8 \mathrm{~m}$ depth during late August when residual currents were heading inwards. In 2005 outward currents dominated at depths of 5,10 and $15 \mathrm{~m}$, and inwards at $8 \mathrm{~m}$. The 5-d mean current speed between 5 and $15 \mathrm{~m}$ depths, before May to September 2004 observation dates, varied between 2.5 and $6.2 \mathrm{~cm} \mathrm{~s}^{-1}$, and from June to September 2005 between 2.2 and $7.0 \mathrm{~cm} \mathrm{~s}^{-1}$.

Wind observations at the anchored upwelling platform (Fig. 1) in June to August 2005 showed that an inwards wind direction from the west was dominant and the wind speed (24 h running means) varied between 0 and $5 \mathrm{~m} \mathrm{~s}^{-1}$. The exception was a period from 1 to 6 July when the dominant wind direction was outwards from the east, with maximum wind speeds (24 $\mathrm{h}$ running means) of about $10 \mathrm{~m} \mathrm{~s}^{-1}$. The strongest currents observed during the artificial upwelling period in 2005 occurred during this windy period. In 2004 there were no current observations at Geitaneset (Stn 16) before 29 May, 6 June and 13 June. Wind observations at a meteorological station just north of the Lysefjord showed strong northwesterly winds (10 to $\left.15 \mathrm{~m} \mathrm{~s}^{-1}\right)$ before 29 May and calm weather $\left(<2 \mathrm{~m} \mathrm{~s}^{-1}\right)$ between 1 and 13 June. On the basis of mean current observations together with accompanying wind conditions at this station, we estimated that the 5 -d average current speed in the 5 to $15 \mathrm{~m}$ layer was about $6 \mathrm{~cm} \mathrm{~s}^{-1}$ on 29 May and $3 \mathrm{~cm} \mathrm{~s}^{-1}$ on 6 and 13 June. The 5-d mean of water transport between 5 and $15 \mathrm{~m}$ depth previous to observation dates in 2004 and $2005\left(Q_{\mathrm{v}}\right)$ varied between 160 and $460 \mathrm{~m}^{3} \mathrm{~s}^{-1}$, giving a mean transport of $260 \mathrm{~m}^{3} \mathrm{~s}^{-1}$.

In June 2005 the irradiances (PAR) at $0.5 \mathrm{~m}$ depth at Stn 02 and outside Lysefjord at Stn 03 were 1950 umol photons $\mathrm{m}^{-2} \mathrm{~s}^{-1}$ (clear weather) and $707 \mu \mathrm{mol}$ photons $\mathrm{m}^{-2} \mathrm{~s}^{-1}$ (cloudy). The $1 \%$ light depths, at which PAR irradiances are reduced to $1 \%$ of the surface values, were about 15 and $24 \mathrm{~m}$, respectively.

\section{Nutrients and particulate organic carbon}

In the upper $50 \mathrm{~m}$ of the water column in the inner part of the Lysefjord, concentrations of nitrate $(\mathrm{N})$ ranged from 0 to $17 \mathrm{mmol} \mathrm{m}^{-3}$, silicate (Si) from 0.3 to $23 \mathrm{mmol} \mathrm{m}^{-3}$ and orthophosphate $\left(\mathrm{P}_{\mathrm{i}}\right)$ from 0 to $1.5 \mathrm{mmol} \mathrm{m}^{-3}$ from May to September in 2004 and 2005. Typical of this period were low nutrient concentrations in the upper $10 \mathrm{~m}$ of the water column and increasing concentrations below $10 \mathrm{~m}$ depth, exemplified by the profile at Stn 17 on 21 June 2005 (Fig. 4). The relatively stable vertical distribution of nutrients below $10 \mathrm{~m}$ depth is an effect of the shallow sill depth 


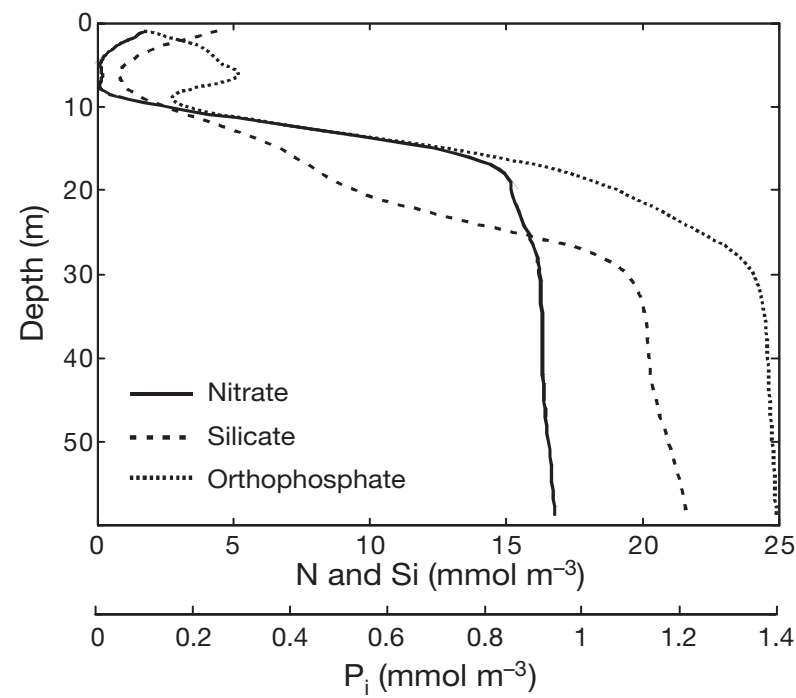

Fig. 4. Typical vertical profiles of nitrate $(\mathrm{N})$, silicate $(\mathrm{Si})$ and orthophosphate $\left(\mathrm{P}_{\mathrm{i}}\right)$ in the inner part of the Lysefjord during the artificial upwelling experiments (Stn 17 on 21 June 2005)

of $14 \mathrm{~m}$ at the inlet of the Lysefjord. In the mixing layer of the artificial upwelling between 10 and $30 \mathrm{~m}$, where the submerged brackish water rises upwards, the mean nutrient values were considerably higher than in the upper $10 \mathrm{~m}$ layer (Table 1). In the 10 to $30 \mathrm{~m}$ layer the elemental ratios $\left(\mathrm{N}: \mathrm{Si}: \mathrm{P}_{\mathrm{i}}=13: 11: 1\right)$ were quite close to ratios observed in deep waters in other Norwegian fjords (N:Si: $\left.P_{i}=11: 14: 1\right)$ (Stigebrandt \& Aure 1988).

At Stns 02, 01, 17, 16 and 11, the POC values varied between 38 and $517 \mathrm{mg} \mathrm{m}^{-3}$. Maximum values of POC in the water column were found between 3 and $7 \mathrm{~m}$, but the maxima were most frequent at about $7 \mathrm{~m}$. The highest POC value of $517 \mathrm{mg} \mathrm{m}^{-3}$ during the upwelling period in 2005 was at $7 \mathrm{~m}$ at Stn 11 on 17 August. The high correlation between POC and in situ turbidity in $2005\left(R^{2}=0.8, n=43\right)$ shows that the upper $20 \mathrm{~m}$ of the Lysefjord was dominated by organic particles such as phytoplankton and detritus. In the main artificial upwelling influence layer between 5 and $15 \mathrm{~m}$ depth, the $\mathrm{R}^{2}$ between POC and in situ chl a was 0.8 , and the mean POC:chl a ratio was 80:1 $(\mathrm{n}=43)$. water and $M^{*}$, the intrusion depths $\left(Z_{\mathrm{i}}\right)$ were estimated to vary between 7 and $11 \mathrm{~m}$ in 2004 and 2005, with an average of 8 to $9 \mathrm{~m}$. This fits well with the observed mean chl a maximum depth of $7.0 \mathrm{~m}$ at Stn 11 during the upwelling period from June to September 2005. The total mixing $\left(Q_{\mathrm{s}} / Q_{\mathrm{b}}\right)$ between 30 and $10 \mathrm{~m}$ depth at the platform location was about 14.0 . With $Q_{\mathrm{b}}=2 \mathrm{~m}^{3} \mathrm{~s}^{-1}$ the supply of deeper seawater $\left(Q_{\mathrm{s}}\right)$ to $10 \mathrm{~m}$ depth was then $28 \mathrm{~m}^{3} \mathrm{~s}^{-1}$. This is about $12 \%$ of the total observed mean water exchange between 5 and $15 \mathrm{~m}$ depths in the inner part of the fjord. Based on both the mean concentrations of nutrients in 2004 and 2005 (Table 1) and the estimated transport of water between 30 to $10 \mathrm{~m}$ depths, the artificial upwelling supply of nutrients was estimated to $450 \mathrm{~kg} \mathrm{~d}^{-1} \mathrm{~N}, 750 \mathrm{~kg} \mathrm{~d}^{-1} \mathrm{Si}$ and $70 \mathrm{~kg} \mathrm{~d}^{-1} \mathrm{P}_{\mathrm{i}}$.

\section{Primary production rates June 2005}

The daily integrated primary production rate between surface and $20 \mathrm{~m}$ depths in the Lysefjord at Stn 17 on 22 June and at Stn 03 (Fig. 1) on 24 June were approximately $350 \mathrm{mg} \mathrm{C} \mathrm{m} \mathrm{d} \mathrm{d}^{-1}$. Carbon assimilation rates at fixed depths varied between 0 and $2.8 \mathrm{mg} \mathrm{C}$ $\mathrm{m}^{-3} \mathrm{~h}^{-1}$ at Stn 17 and between 0 and $2.3 \mathrm{mg} \mathrm{C} \mathrm{m}{ }^{-3} \mathrm{~h}^{-1}$ at Stn 03, with the highest values occurring within the upper 0 to $3 \mathrm{~m}$ layer. From this we conclude that the difference in primary production rate between the Lysefjord and Høgsfjord was insignificant before the onset of the artificial upwelling in late June 2005 (see Fig. 7a).

\section{Estimated artificial upwelling primary production rate}

The primary production rate $\left(\mathrm{P}_{\mathrm{upw}}\right)$ measured as $\mathrm{kg} \mathrm{C}$ $\mathrm{d}^{-1}$ due to the artificial upwelling is estimated by:

$$
\mathrm{P}_{\mathrm{upw}}=\mathrm{PHOS}_{\mathrm{upw}} \cdot(\mathrm{POC} / \mathrm{POP}) \cdot R
$$

where PHOS $_{\text {upw }}\left(70 \mathrm{~kg} \mathrm{~d}^{-1}\right)$ is the mean supply of phosphate to the photic layer due to artificial upwelling,

\section{Intrusion depth and supply of deep water}

The average mixing rate, $M^{*}=$ $\left(Q_{\mathrm{s}} / Q_{\mathrm{b}}\right) /\left(Z_{30}-Z_{\mathrm{i}}\right)$, between brackish $\left(Q_{\mathrm{b}}, \mathrm{m}^{3} \mathrm{~s}^{-1}\right)$ and seawater $\left(Q_{\mathrm{s}}, \mathrm{m}^{3} \mathrm{~s}^{-1}\right)$ from the outlet depth $\left(Z_{30}\right)$ to the intrusion depth $\left(Z_{\mathrm{i}}\right)$ was estimated as $0.8 \mathrm{~m}^{-1}$. On the basis of vertical density profiles in 2004 and 2005, the density of the submerged brackish
Table 1. Mean concentrations of nitrate $(\mathrm{N})$, phosphate $\left(\mathrm{P}_{\mathrm{i}}\right)$ and silicate $(\mathrm{Si})$ $\left(\mathrm{mmol} \mathrm{m}{ }^{-3}\right.$ ) and $\mathrm{N} / \mathrm{P}_{\mathrm{i}}, \mathrm{Si} / \mathrm{P}_{\mathrm{i}}$ at depths of 0 to $10 \mathrm{~m}$ and 10 to $30 \mathrm{~m}$ at $\mathrm{Stn} 11$, from May to September in the Lysefjord in 2004 and 2005

\begin{tabular}{|ccccccc|}
\hline Year & $\begin{array}{c}\text { Depth } \\
(\mathrm{m})\end{array}$ & $\begin{array}{c}\mathrm{N} \\
\left(\mathrm{mmol} \mathrm{m}^{-3}\right)\end{array}$ & $\begin{array}{c}\mathrm{Si} \\
\left(\mathrm{mmol} \mathrm{m}^{-3}\right)\end{array}$ & $\begin{array}{c}\mathrm{P}_{\mathrm{i}} \\
\left(\mathrm{mmol} \mathrm{m}^{-3}\right)\end{array}$ & $\mathrm{N} / \mathrm{P}_{\mathrm{i}}$ & $\mathrm{Si} / \mathrm{P}_{\mathrm{i}}$ \\
\hline 2004 & $0-10$ & 0.9 & 2.1 & 0.1 & 6.9 & 16 \\
2005 & $0-10$ & 1.8 & 4.4 & 0.3 & 5.4 & 13.3 \\
2004 & $10-30$ & 10.3 & 8.1 & 0.8 & 13.2 & 10.4 \\
2005 & $10-30$ & 12.7 & 11.3 & 0.9 & 13.9 & 12.4 \\
\hline
\end{tabular}


POC/POP $=41$ according to the Redfield ratio and $R$ is the ratio between total and new production; $R=2.3$ is a typical value for southern Norwegian marine waters (Wassmann 1990, Skjoldal \& Wassmann 1986). Using Eq. (1) $P_{\text {upw }}$ is estimated to be $6600 \mathrm{~kg} \mathrm{C} \mathrm{d}^{-1}$.

The natural production rate $\left(P_{\mathrm{n}}\right)$ measured as $\mathrm{kg} \mathrm{C}$ $\mathrm{d}^{-1}$ inside a given area $\left(A, \mathrm{~km}^{2}\right)$ is:

$$
P_{\mathrm{n}}=\mathrm{p}_{\mathrm{n}} \cdot A
$$

where $p_{\mathrm{n}}$ is the average primary production rate per $\mathrm{m}^{2}$ below the upper brackish layer. The total primary production rate (PT) is then the sum of $P_{\text {upw }}$ and $P_{\mathrm{n}}$, since the water and related natural phytoplankton exchange with the external fjord system is not significantly influenced by the artificial upwelling (see previous explanation). Typical mean daily integrals of carbon assimilation in the euphotic zone in fjords for the period from April to September are 500 to $600 \mathrm{mg} \mathrm{C} \mathrm{m} \mathrm{m}^{-2} \mathrm{~d}^{-1}$, with about one-half occurring below the upper brackish layer $\left(p_{\mathrm{n}}=300 \mathrm{mg} \mathrm{C} \mathrm{m} \mathrm{d}^{-1}\right.$ ) (Erga 1989b, Erga et al. 2005).

The area of influence $\left(\mathrm{A}_{\text {infl }}\right)$ is defined as the area where the phytoplankton biomass and the primary production rate are significantly stimulated by the artificial upwelling. Investigation of the longitudinal distribution of chl $a$ in the Lysefjord during artificial upwelling in 2004 and 2005 (Fig. 5a) showed that in all cases, except on 29 May 2004 and 6 June 2005, the area of influence was $10 \mathrm{~km}^{2}$ or less, e.g. inside Stn 01 (Fig. 1). On 29 May and 6 June 2005 currents and water exchange were considerably increased and a greater proportion of chl a existed outside the area of $10 \mathrm{~km}^{2}$. On basis of these observations our main fixed observation area $\left(A_{0}\right)$ is selected to be the inner $10 \mathrm{~km}^{2}$ of the Lysefjord (Fig. 1). Using $A=\mathrm{A}_{\mathrm{o}}$ in Eq. (2), the natural production $\left(P_{\mathrm{n}}\right)$ is estimated to be $3000 \mathrm{~kg} \mathrm{C}$. The total primary production rate $\mathrm{PT}=P_{\mathrm{upw}}+P_{\mathrm{n}}$ caused by the increased supply of nutrients to the euphotic layer is then calculated to be $9600 \mathrm{~kg} \mathrm{C} \mathrm{d}^{-1}$, i.e. an increase of the primary production rate $\left(\mathrm{PT} / P_{\mathrm{n}}\right)$ by a factor of about 3 .

In a steady-state situation the total upwelling primary production rate (PT) measured as $\mathrm{kg} \mathrm{C} \mathrm{d}^{-1}$ inside $\mathrm{A}_{\mathrm{o}}$ is balanced with the transport of carbon $\left(Q_{\mathrm{V}} \cdot C m_{\mathrm{upw}}\right)$ leaving $\mathrm{A}_{\mathrm{o}}$, where $Q_{\mathrm{V}}$ is the water transport in the layer influenced of the artificial upwelling and $\mathrm{Cm}_{\mathrm{upw}}$ is the mean carbon concentration inside $\mathrm{A}_{\mathrm{o}}$, i.e.

$$
\mathrm{PT}=Q_{\mathrm{v}} \cdot C m_{\mathrm{upw}}
$$

With $C m_{\text {upw }}=\mathrm{CT}_{\text {upw }} /\left(\mathrm{A}_{\mathrm{o}} \cdot H_{\mathrm{a}}\right)$ we get:

$$
\mathrm{PT}=\mathrm{ChlT}_{\text {upw }} /\left(\mathrm{A}_{\mathrm{o}} \cdot H_{\mathrm{a}}\right) \cdot Q_{\mathrm{v}} \cdot(\mathrm{POC} / \mathrm{chl} a)
$$

where $\mathrm{CT}_{\text {upw }}$ and $\mathrm{ChlT}_{\text {upw }}$ are the total carbon and chl $a$ inside $\mathrm{A}_{0}, H_{\mathrm{a}}$ is the mean thickness of the plankton layer influenced by the artificial upwelling and
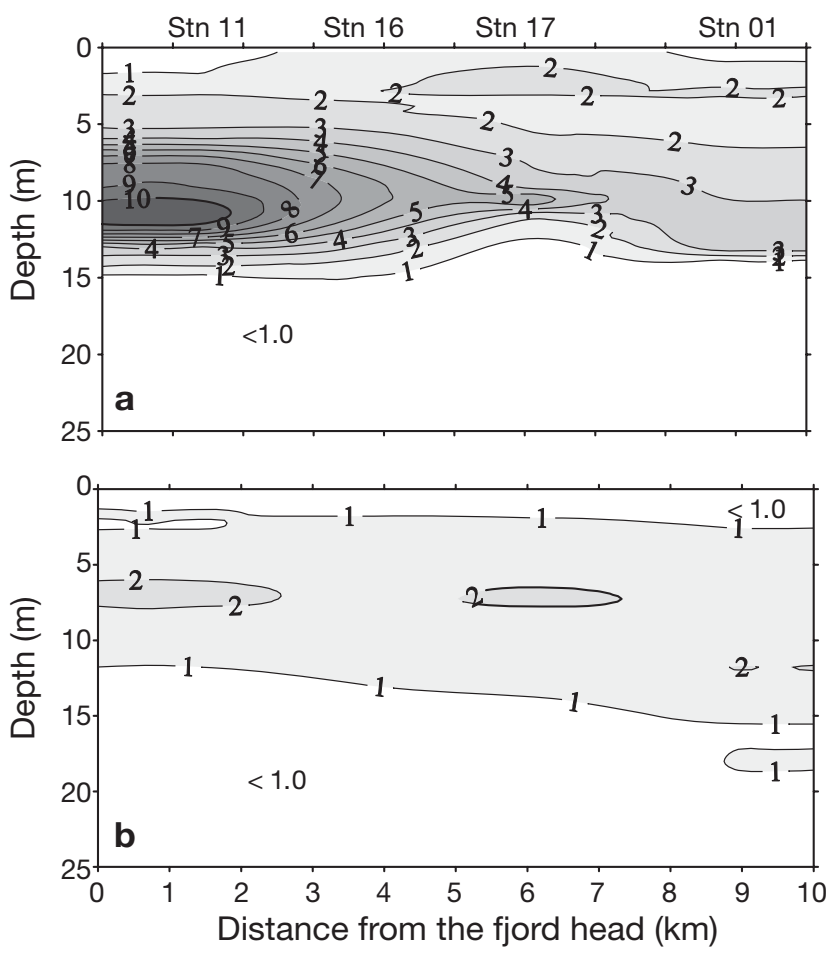

Fig. 5. Typical vertical distribution of chl a $\left(\mathrm{mg} \mathrm{m}^{-3}\right)$ between 0 and $25 \mathrm{~m}$ depths in the inner $10 \mathrm{~km}$ of the Lysefjord (a) with artificial upwelling (22 July 2005) and (b) during natural conditions (30 August 2005)

$\mathrm{POC} / \mathrm{chl} \mathrm{a}$ is the ratio between particulate organic carbon and chl a. The total chl $a$ inside $\mathrm{A}_{\mathrm{o}}\left(\mathrm{ChlT}_{\text {upw }}\right.$ measured as $\mathrm{kg} \mathrm{chl} \mathrm{a)} \mathrm{is} \mathrm{then:}$

$$
\mathrm{ChlT}_{\text {upw }}=\mathrm{PT} \cdot\left(\mathrm{A}_{\mathrm{o}} \cdot H_{\mathrm{a}}\right) /(\mathrm{POC} / \mathrm{chl} a) / Q_{\mathrm{v}}
$$

This relation shows that $\mathrm{ChlT}_{\text {upw }}$ inside $\mathrm{A}_{\mathrm{o}}$ is also expected to increase by a factor of 3 during the artificial upwelling experiment.

\section{Observed effects of artificial upwelling}

Mean chl a values in the 4 to 15 m layer at Stn 11 in the inner part and at Stn 2 in the middle of the Lysefjord (Fig. 1) were, respectively, $1.7 \mathrm{mg} \mathrm{m}^{-3}(\mathrm{SD}=0.7$, $\mathrm{n}=335)$ and $1.6 \mathrm{mg} \mathrm{m}^{-3}(\mathrm{SD}=0.6, \mathrm{n}=335$, ) during the May to September periods from 2002 to 2006, excluding the artificial upwelling periods in 2004 and 2005. Chl $a$ values in the range 1 to $2 \mathrm{mg} \mathrm{m}^{-3}$ are typical for the upper $10 \mathrm{~m}$ of the water column in fjords during summer when nutrients are scarce (Aure et al. 2000). This confirms that the horizontal differences of chl a between the inner and middle fjord are insignificant during natural conditions. To examine the effects of the artificial upwelling experiment, observed chl a was integrated in the 4 to $15 \mathrm{~m}$ layer within $\mathrm{A}_{\mathrm{o}}$, both in 
situations with $\left(\mathrm{ChlT}_{\text {upw }}\right)$ and without $\left(\mathrm{ChlT}_{\mathrm{n}}\right)$ artificial upwelling. Examples of typical vertical distributions of chl $a$ inside $\mathrm{A}_{\mathrm{o}}$ both with artificial upwelling and during natural conditions are shown in Fig. 5.

In 2004 the artificial upwelling was started on 19 May. After a period with strong northerly winds and currents in late May, weather conditions became calmer, and $\mathrm{ChlT}_{\text {upw }}$ values increased from $167 \mathrm{~kg}$ on 29 May to 400 to $500 \mathrm{~kg}$ in June (Fig. 6a). On 27 July

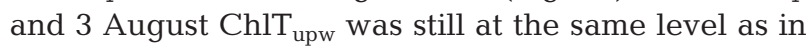
June. On 17 August ChlT was reduced to about $130 \mathrm{~kg}$ even though the current and wind conditions were still moderate. This anomalously low value was related to a collapse in the diatom stock inside $\mathrm{A}_{\mathrm{o}}$ (discussed later). The artificial upwelling system stopped on 24 August. After this date the integrated chl $a$ inside $\mathrm{A}_{\mathrm{o}}$ decreased to about $100 \mathrm{~kg}$. In the artificial upwelling period from 6 June to 3 August 2004 the mean $\mathrm{ChlT}_{\text {upw }}$ was about $480 \mathrm{~kg}\left(48 \mathrm{mg} \mathrm{m}^{-2}\right)$, excluding 29 May 2004 when $\mathrm{A}_{\text {infl }}$ was much greater than $\mathrm{A}_{\mathrm{o}}$ and the diatom collapse on 17 August 2004. The mean chl a concentration

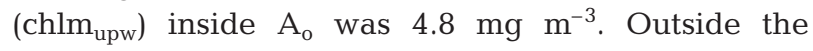
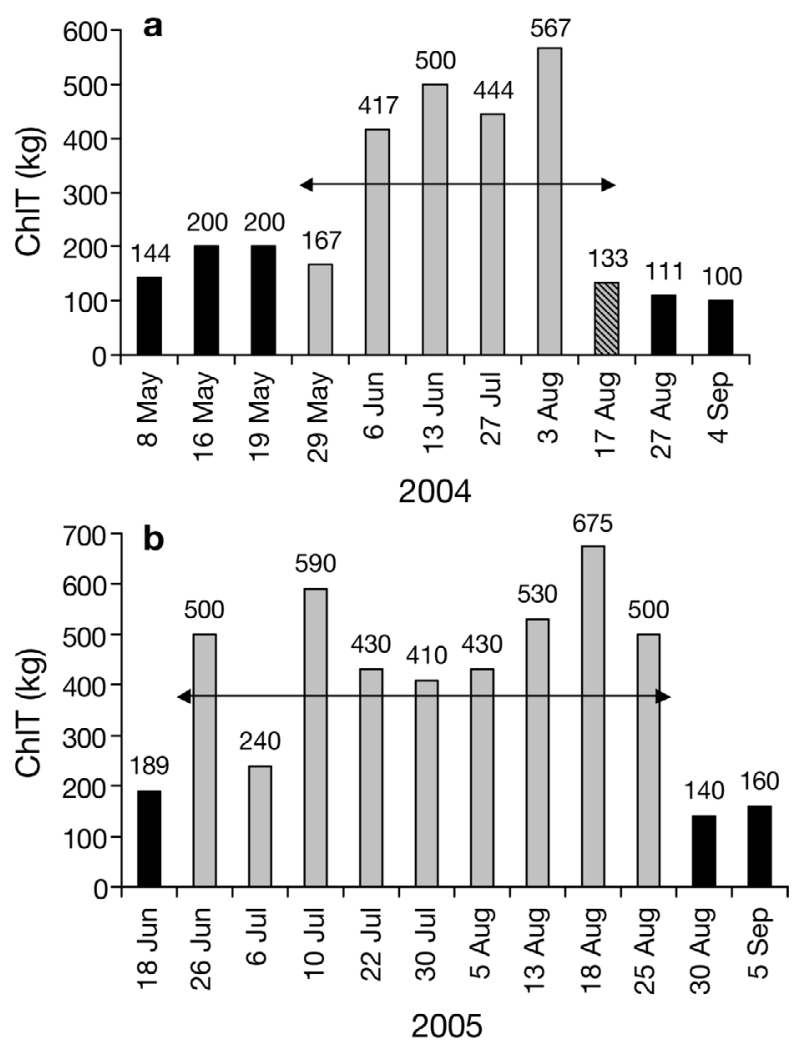

Fig. 6. Integrated chl a (ChlT, kg) from below the surface layer to $15-20 \mathrm{~m}$ depth inside $\mathrm{A}_{\mathrm{o}}\left(=10 \mathrm{~km}^{2}\right)$ in the inner part of the Lysefjord. (a) 8 May to 4 September 2004 and (b) 18 June to 5 September 2005 (grey columns and horizontal arrow $=$ artificial upwelling response periods, black columns = natural conditions, hatched column $=$ phytoplankton [diatom] collapse on 17 August 2004) upwelling period in May and late August to September 2004 the mean $\mathrm{ChlT}_{\mathrm{n}}$ was $155 \mathrm{~kg}\left(15.5 \mathrm{mg} \mathrm{m}^{-2}\right)$ and the mean chl a concentration $\left(\operatorname{chlm}_{\mathrm{n}}\right)$ was $1.9 \mathrm{mg} \mathrm{m}^{-3}$ inside $\mathrm{A}_{\mathrm{o}}$. ChlT $\mathrm{T}_{\text {upw }}$ then increased by a factor of about

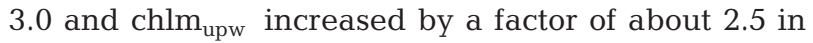
the artificial upwelling period from June to the first part of August 2004.

In 2005 the artificial upwelling was started on 18 June and was closed down on 27 August. The daily observations during the first week of upwelling (Fig. 7a) showed that chl $a$ integrated between the surface layer and $15 \mathrm{~m}$ depth (ChlI, $\mathrm{mg} \mathrm{m}^{-2}$ ) at Stn 11 inside $\mathrm{A}_{\mathrm{o}}$ increased from $20 \mathrm{mg} \mathrm{m}^{-2}$ on 18 June to a maximum of 60 to $70 \mathrm{mg} \mathrm{m}^{-2}$ on $25-26$ June. The time needed to establish a fully developed artificial upwelling, thus, appears to be about $1 \mathrm{wk}$. During this period Chll at Stn 11 increased by a factor of about 3 relative to Stn 02 outside $\mathrm{A}_{\mathrm{o}}$ and the mean daily increase of ChlI after 21 June was about $23 \%$.

During the period from 26 June to 25 August 2005, while the artificial upwelling was in progress, ChlI (mg $\mathrm{m}^{-2}$ ) values were significantly higher at Stn 11 than at the reference station, Stn 02 (Fig. 7b). At Stn 11, ChlI varied between 53 and $73 \mathrm{mg} \mathrm{m}^{-2}$, with the exception
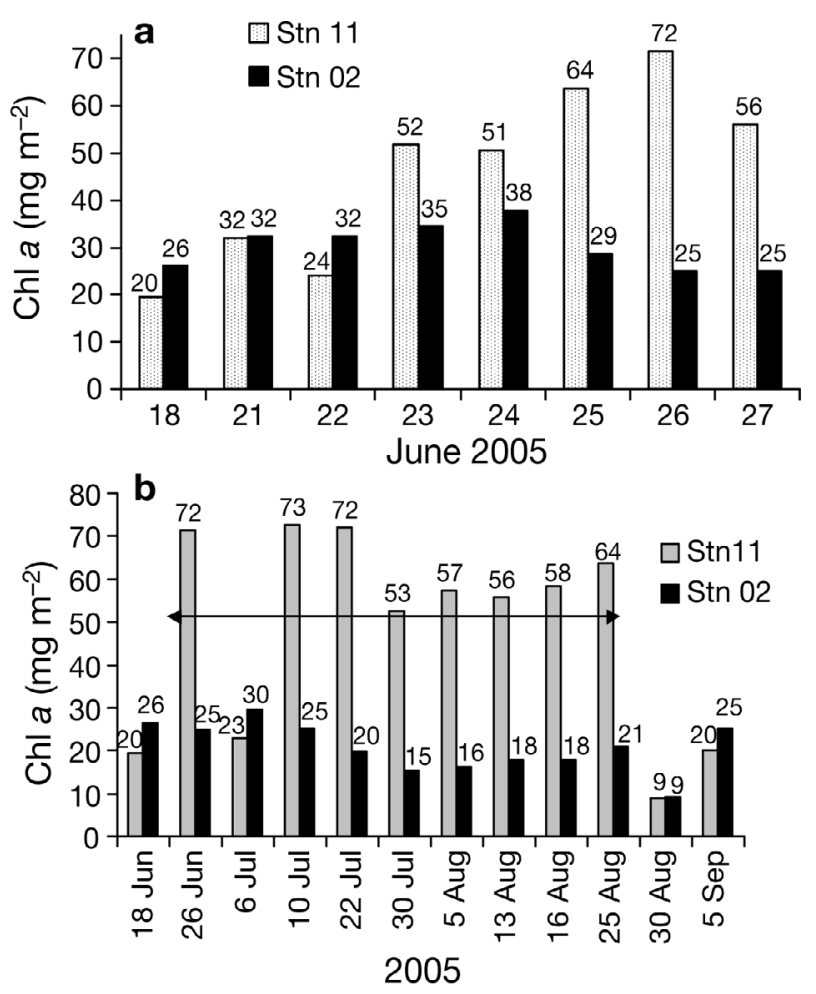

Fig. 7. (a) Vertical integrated chl a $\left(\mathrm{mg} \mathrm{m}^{-2}\right)$ at Stns 11 and 02 during the period 18 to 27 June 2005 (artificial upwelling commenced on 18 June). (b) Vertically integrated chl a (mg $\mathrm{m}^{-2}$ ) at Stns 11 and 02 from 18 June to 5 September 2005 (horizontal arrow $=$ artificial response upwelling period) 
of 6 July when ChlI was reduced to $23 \mathrm{~kg}$ due to a considerable increase in out-fjord wind speed and consequently higher water exchange $\left(A_{\text {infl }}>>A_{0}\right)$. At the reference station (Stn 02) ChlI varied between 15 and $30 \mathrm{mg} \mathrm{m}^{-2}$ in the same period. Mean Chll values at Stn 11 (excluding 6 July when $A_{\text {infl }}>A_{o}$ ) and Stn 02 during the artificial upwelling period were about 60 and $20 \mathrm{mg} \mathrm{m}^{-2}$, respectively. The mean chl a concentration (chlm) showed a similar pattern as ChlI, and at Stn 11 it varied between 5.3 and $10.5 \mathrm{mg} \mathrm{m}^{-3}$, with the exception of 6 July where chlm was $3.3 \mathrm{mg} \mathrm{m}^{-3}$. At Stn $02 \mathrm{chlm}$ varied between 1.7 and $3.3 \mathrm{mg} \mathrm{m}^{-3}$. The average chlm was $6.5 \mathrm{mg} \mathrm{m}^{-3}$ at Stn 11 and $2.2 \mathrm{mg} \mathrm{m}^{-3}$ at Stn 02. Both mean Chll and chlm inside $A_{o}$ were then about 3 times as high at Stn 11 as at the reference station, Stn 02. In the artificial upwelling period the typical thickness of the phytoplankton layer $\left(\mathrm{H}_{\mathrm{a}}\right)$ and the mean chl a maximum depth at both Stn 11 and 02 were 9 to $10 \mathrm{~m}$ and $7 \mathrm{~m}$, respectively.

In the upwelling period from 26 June to 25 August 2005 the integrated chl a inside $\mathrm{A}_{\mathrm{o}}\left(\mathrm{ChlT}_{\mathrm{upw}}\right)$ varied between 410 and $675 \mathrm{~kg}$, except on 6 July when $A_{\text {infl }}$ was much greater than $\mathrm{A}_{\mathrm{o}}$ (Fig. 6b). The mean $\mathrm{ChlT}_{\text {upw }}$ excluding 6 July ( $\mathrm{A}_{\text {infl }}>>$ Ao), was $510 \mathrm{~kg}\left(51 \mathrm{mg} \mathrm{m}^{-2}\right)$ and the mean chl a concentration ( $\mathrm{chlm}_{\text {upw }}$ ) was $5.3 \mathrm{mg}$ $\mathrm{m}^{-3}$. During natural conditions, the integrated chl $a$ inside $\mathrm{A}_{\mathrm{o}}\left(\mathrm{ChlT}_{\mathrm{n}}\right)$ was $163 \mathrm{~kg}\left(16 \mathrm{mg} \mathrm{m}^{-2}\right)$ and the mean natural chl a concentration $\left(\operatorname{chlm}_{\mathrm{n}}\right)$ was $1.7 \mathrm{mg} \mathrm{m}^{-3}$.

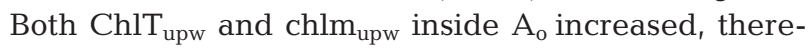
fore, by a factor of about 3 in the artificial upwelling period from June to August 2005. The observed mean natural $\mathrm{ChlT}_{\mathrm{n}}$ of $160 \mathrm{~kg}$ between the 4 and $15 \mathrm{~m}$ depths in 2004 and 2005 was almost identical to the observed mean $\mathrm{ChlT}_{\mathrm{n}}$ of $165 \mathrm{~kg}(\mathrm{SD}=35 \mathrm{~kg}, \mathrm{n}=16)$ at Stns 11, 16, 17 and 01 inside $A_{o}$ from May to September in 2002, 2003 and 2006.

Fig. 8 shows that there is a high correlation between observed ChlT inside $\mathrm{A}_{\mathrm{o}}$ and the water transport $\left(Q_{\mathrm{V}}\right.$ $\left.\mathrm{m}^{3} \mathrm{~s}^{-1}\right)$. ChlT $\mathrm{upw}_{\text {, }}$ and the difference between $\mathrm{ChlT}_{\text {upw }}$ and $\mathrm{ChlT}_{\mathrm{n}}$ are decreasing with increasing $Q_{\mathrm{v}}$ and with the largest relative changes appearing at low $Q_{\mathrm{v}}$. When $Q_{\mathrm{V}}$ is less than $260 \mathrm{~m}^{3} \mathrm{~s}^{-1}$ the observed influence area of the artificial upwelling is less than $\mathrm{A}_{\mathrm{o}}=10 \mathrm{~km}^{2}$. The mean total primary production rate $(\mathrm{PT})$ inside $\mathrm{A}_{\mathrm{o}}$ $\left(\mathrm{A}_{\text {infl }} \leq \mathrm{A}_{\mathrm{o}}\right)$ during artificial upwelling is calculated using the observed mean of $\mathrm{ChlT}_{\text {upw }}(500 \mathrm{~kg})$ and $Q_{\mathrm{v}}$ $\left(235 \mathrm{~m}^{3} \mathrm{~s}^{-1}\right)$ in Eq. (4). Natural production, $P_{\mathrm{n}}$, is calculated using $\mathrm{ChlT}_{\mathrm{n}}=180 \mathrm{~kg}$ and the related mean $Q_{\mathrm{v}}=$ $225 \mathrm{~m}^{3} \mathrm{~s}^{-1}$. When $H_{\mathrm{a}}=9 \mathrm{~m}$ and POC/chl $\mathrm{a}=80, \mathrm{PT}$ and $P_{\mathrm{n}}$ are estimated to be approximately $9000 \mathrm{~kg} \mathrm{C} \mathrm{d}^{-1}$ (900 $\mathrm{mg} \mathrm{C} \mathrm{m}^{-2} \mathrm{~d}^{-1}$ ) and $3000 \mathrm{~kg} \mathrm{C} \mathrm{d}^{-1}$ (300 $\mathrm{mg} \mathrm{C} \mathrm{m}^{-2}$ $\mathrm{d}^{-1}$ ), respectively. PT and $P_{\mathrm{n}}$ measured as $\mathrm{kg} \mathrm{C} \mathrm{d}^{-1}$ may also be expressed as:

$$
\mathrm{PT}\left(P_{\mathrm{n}}\right)=k \cdot \operatorname{ChlT}_{\text {upw }(\mathrm{n})}
$$

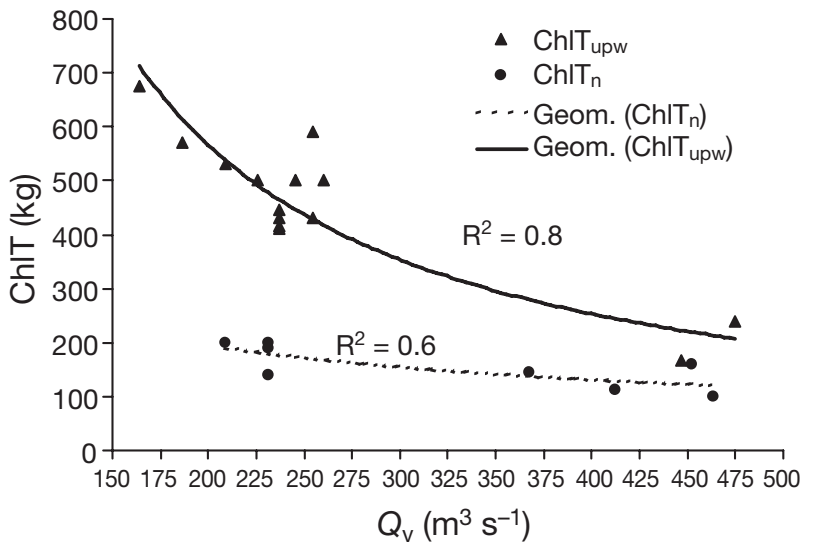

Fig. 8. Observed relationships between the water transport $\left(Q_{\mathrm{V}}\right)$ and the total chl $a$ inside $\mathrm{A}_{\mathrm{o}}(\mathrm{ChlT})$ in the inner part of the Lysefjord. ChlT from artificial upwelling $=\mathrm{ChlT}_{\text {upw }}$, and ChlT from natural conditions $=\mathrm{ChlT}_{\mathrm{n}}$. Geometric regression lines and related $R^{2}$ are included

where $k$ is the photosynthetic effectiveness (daily integrals of vertically integrated carbon assimilation over chl a, mg C mg chl $a^{-1} \mathrm{~d}^{-1}$ ) (Prasad et al. 1995, Erga et al. 2005) and $\mathrm{ChlT}_{\text {upw (n) }}$ is the mean total chl a inside $\mathrm{A}_{\mathrm{o}}$. Possible losses of chl a due to sedimentation are not taken into account, but they are probably low under continuous upwelling and stratified conditions (Riebesell 1989). The restricted residence time of the phytoplankton layer $(5 \mathrm{~d})$ inside $A_{o}$ and the low sinking velocity of healthy algae $\left(<1 \mathrm{~m} \mathrm{~d}^{-1}\right)$ support this assumption. The mean PT and $P_{\mathrm{n}}$ inside $\mathrm{A}_{\mathrm{o}}$ are calculated using the observed mean of $\mathrm{ChlT}_{\text {upw }}(500 \mathrm{~kg})$ in 2004 and 2005 and $\mathrm{ChlT}_{\mathrm{n}}(165 \mathrm{~kg})$ in the period from 2002 to 2006 in Eq. (6). Using $k=18 \mathrm{mg} \mathrm{C} \mathrm{mg} \mathrm{chl} a^{-1}$ $\mathrm{d}^{-1}$, a value representative of average growth conditions during the summer season in southwestern Norwegian fjords (Erga et al. 2005, S. Erga unpubl. data from adjacent fjords), Eq. (6) gives a total artificial upwelling production (PT) of $9000 \mathrm{~kg} \mathrm{C} \mathrm{d}^{-1}$ (900 mg C $\mathrm{m}^{-2} \mathrm{~d}^{-1}$ ) and a natural production $\left(\mathrm{P}_{\mathrm{n}}\right)$ of $2950 \mathrm{~kg} \mathrm{C} \mathrm{d}^{-1}$ (295 mg C m $\mathrm{m}^{-2} \mathrm{~d}^{-1}$ ).

Both methods give a total artificial upwelling production (PT) of approximately $9000 \mathrm{~kg} \mathrm{C} \mathrm{d}^{-1}$ (900 mg $\left.\mathrm{C} \mathrm{m} \mathrm{m}^{-2} \mathrm{~d}^{-1}\right)$ and a natural production $\left(P_{\mathrm{n}}\right)$ inside $\mathrm{A}_{\mathrm{o}}$ of approximately $3000 \mathrm{~kg} \mathrm{C} \mathrm{d}{ }^{-1}\left(300 \mathrm{mg} \mathrm{C} \mathrm{m}^{-2} \mathrm{~d}^{-1}\right)$. The estimated $P_{\mathrm{n}}$ is close to the observed typical natural production of $3000 \mathrm{~kg} \mathrm{C} \mathrm{d} \mathrm{d}^{-1}$ (300 mg C m $\mathrm{m} \mathrm{d}^{-1}$ ) below the surface layer in the summer period. The primary production rate due to the artificial upwelling $\left(P_{\text {upw }}=\mathrm{PT}-P_{\mathrm{n}}\right)$ is then $6000 \mathrm{~kg} \mathrm{C} \mathrm{d}$ (600 $\mathrm{mg} \mathrm{C} \mathrm{m} \mathrm{C}^{-1}$ ) and close agreement with the previously estimated $P_{\text {upw }}=6600 \mathrm{~kg} \mathrm{C} \mathrm{d}^{-1}(660 \mathrm{mg} \mathrm{C}$ $\mathrm{m}^{-2} \mathrm{~d}^{-1}$ ) based on the increased supply of nutrients to the photic layer. 


\section{Phytoplankton composition}

Some days before the artificial upwelling started on 19 May 2004, the phytoplankton stock inside the area of influence of artificial upwelling was dominated by dinoflagellates (Fig. 9a). During June and in the first part of August 2004 there was a considerable relative increase of diatoms with Chaetoceros spp. as the dominant genus. The diatom biomass increased from about $4 \%$ of the total phytoplankton biovolume (sum of diatoms and flagellates) on 29 May to about $41 \%$ on 13 June. During this period the diatom volume biomass increased by $20 \% \mathrm{~d}^{-1}$. On 3 August the diatom biovolume still constituted $84 \%$ of the total biovolume inside $A_{o}$. Outside $A_{o}$ at Stn 02, and in the adjacent Høgsfjord (Stn 03), no diatoms were observed. Here, flagellates including dinoflagellates were the dominant group of phytoplankton in terms of biomass. On 17 August the
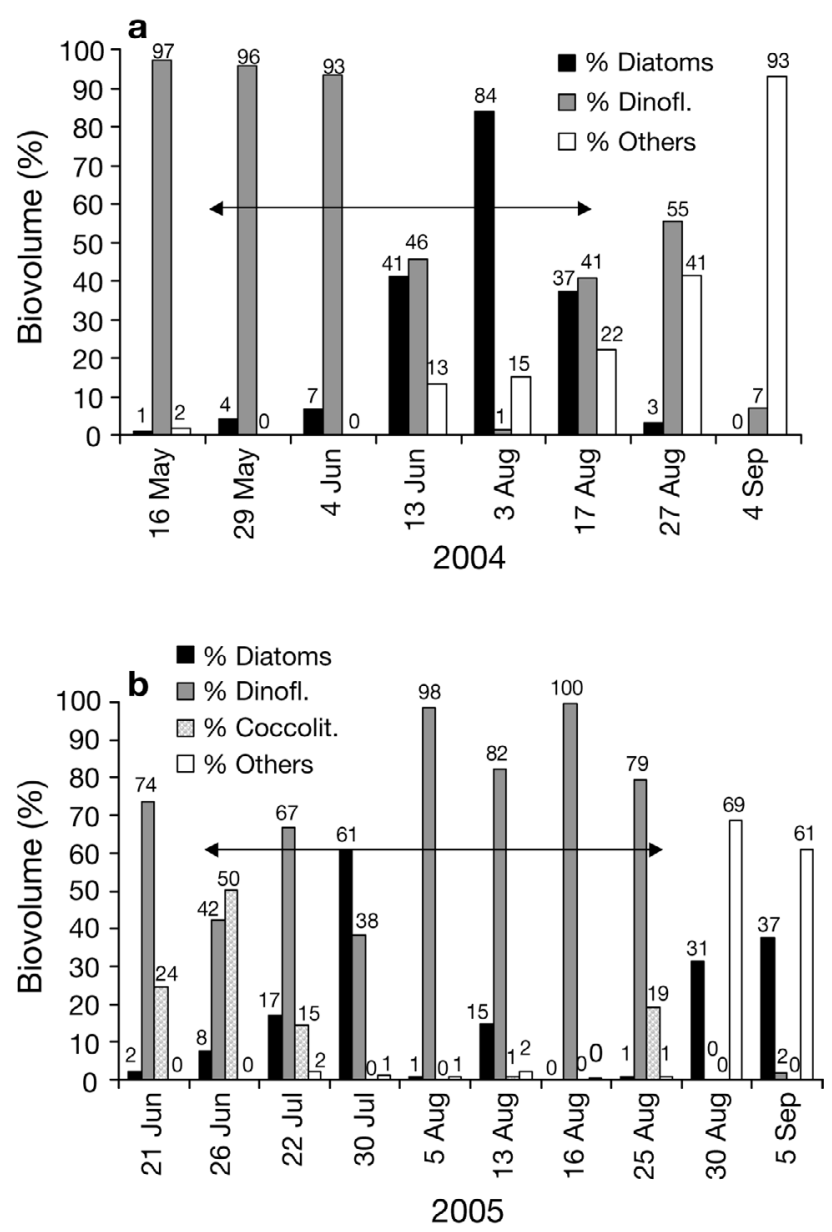

Fig. 9. Percentage biovolume of the most important groups of phytoplankton within the depth interval 7 to $15 \mathrm{~m}$ in the inner part of the Lysefjord during (a) 16 May to 4 September 2004 at Stns 11 and 16, and (b) 21 June to 5 September 2005 at Stn 17, inside the main observation area $\mathrm{A}_{\mathrm{o}}$ (horizontal arrow = artificial response upwelling period, Dinofl. = dinoflagellates, Coccolit. $=$ coccolithophorids) diatom stock was greatly reduced. After the artificial upwelling was stopped in late August, flagellates $<20 \mu \mathrm{m}$ (i.e. dinoflagellates plus others) became the dominant phytoplankton fraction. From June to September 2004, Dinophysis species were only encountered in very low concentrations $\left(<300\right.$ cells $\left.\mathrm{l}^{-1}\right)$ within the depth interval 5 to $20 \mathrm{~m}$ in the Lysefjord. The normal species succession in western Norwegian fjords during summer is that flagellates and dinoflagellates dominate, but occasionally diatoms may occur (Erga 1989a, Erga et al. 2005).

During the initial phase of the artificial upwelling period in late June 2005, a more detailed study of the quantitative distribution of the most important groups of phytoplankton with respect to biomass was carried out. In this phase the phytoplankton inside the area of influence was dominated by dinoflagellates (74\% of the biovolume), while diatoms made up only $2 \%$ of the total (Fig. 9b). The main difference between 2004 and 2005 was the mass occurrence of the coccolithophorid, Emiliania huxleyi, in 2005, which was by far the most important species in late June 2005. The abundance of E. huxleyi increased inwards in the Lysefjord, a pattern that was also observed for the dinoflagellates. Among the dinoflagellates, nontoxic Ceratium lineatum was dominant, while Dinophysis species were present in low concentrations only, both inside and outside the area of influence. The highest concentration of phytoplankton was situated below the brackish layer, from $6 \mathrm{~m}$ and deeper, where E. huxleyi was totally dominant, with concentrations of around 10 to $12 \times 10^{6}$ cells $\mathrm{l}^{-1}$. Among the diatoms, the pennate forms dominated, with Pseudonitzschia spp., Cylindrotheca closterium and Nitzschia longissima being the most important species.

During the first month of the artificial upwelling period (from 21 June to 22 July), diatom concentrations within and outside the area of influence, Stns 17 and 02 , respectively, increased from about $10^{3}$ to $10^{4}$ cells $\mathrm{l}^{-1}$ to about $10^{6}$ cells $\mathrm{l}^{-1}$, but on 30 July the concentrations of diatoms decreased markedly in Stn 02, while they continued to increase to a maximum of $1.5 \times 10^{6}$ cells $1^{-1}$ at $\operatorname{Stn} 17$. Now the dominating species had changed from Pseudonitzschia spp. to Skeletonema sp. In late July the contribution of diatoms rose to about $60 \%$ of the total biovolume (Fig. 9b). In August dinoflagellates once again took over as the dominant fraction in terms of biovolume, with Ceratium lineatum as the dominant species. As in 2004, Dinophysis species were now present in only very low concentrations. In late August when the artificial upwelling was stopped, small flagellates $<5 \mu \mathrm{m}$ (others) dominated and the chl a content of the water column decreased to the same levels as outside the area of influence (Figs. 9b \& 6b). 


\section{DISCUSSION}

\section{Physical controls on primary production rate}

The large-scale experiment in the Lysefjord showed that artificial upwelling enhanced the observed algae biomass and the estimated primary production rate within an area of about $10 \mathrm{~km}^{2}$ during summers in 2004 and 2005. The artificial upwelling also stimulated diatom growth. These results are in accordance with model simulations of primary production rate in a similarly scaled fjord subjected to different scenarios of submerged freshwater discharge (Berntsen et al. 2002). Our study is the first full-scale experiment to use submerged brackish water discharged in a controlled manner to force artificial upwelling in a fjord area and to demonstrate experimentally the significant potential for ecological studies on this topic in fjords.

Previous investigations in western Norwegian fjords have revealed a remarkable consistency with respect to water exchange processes and phytoplankton growth dynamics (Erga \& Heimdal 1984, Erga 1989a,b, Erga et al. 2005). Nutrient limitation usually leads to reduced primary production yields and changes in species composition to a predominance of ultraplankton $(<5 \mu \mathrm{m})$ flagellates and dinoflagellates during the summer period, but still more than $50 \%$ of the annual primary production occurs after the spring diatom blooms. The mean total primary production rate below the surface brackish layer due to artificial upwelling (PT) was determined to be about $900 \mathrm{mg} \mathrm{C} \mathrm{m}{ }^{-2} \mathrm{~d}^{-1}$ inside an area of $10 \mathrm{~km}^{2}$, about 3 times the natural production rate $\left(P_{\mathrm{n}}\right)$. A primary production rate in the euphotic zone of $1500 \mathrm{mg} \mathrm{C} \mathrm{m}^{-2} \mathrm{~d}^{-1}$ is often found in western Norwegian fjords during the main spring bloom in March (Erga \& Heimdal 1984, Erga et al. 2005). Therefore, it ought to be possible to increase primary production rate rates in the Lysefjord to $1500 \mathrm{mg}$ $\mathrm{C} \mathrm{m}^{-2} \mathrm{~d}^{-1}$ during summer by forced upwelling of nutrient rich deeper water. A considerable enhancement of primary production rates due to natural upwelling have also been reported for many of the strong natural upwelling systems in the world, e.g. the northwest coast of South Africa (Brown 1992), northcentral Chile (Rutllant \& Montecino 2002) and northwestern Spain (see Álvarez-Salgado et al. 2005). Maximum primary production rates for these highly productive waters are typically 6000 to $8000 \mathrm{mg} \mathrm{C} \mathrm{m}{ }^{-2} \mathrm{~d}^{-1}$, considerable higher than primary production rates during the spring bloom in Norwegian fjord waters.

A nutrient enrichment experiment using mesocosms (plastic cylinders) in Lindåspollene, a landlocked fjord system north of Bergen (Aksnes et al. 1985), demonstrated that an artificial upwelling rate corresponding to approximately $1 \mathrm{~m} \mathrm{~d}^{-1}$ resulted in an 8 to 10 -fold increase in the midsummer primary production rate. The upwelling rate inside $A_{o}\left(10 \mathrm{~km}^{2}\right)$ in this experiment was approximately $0.3 \mathrm{~m} \mathrm{~d}^{-1}$, and with an observed production enhancement factor of about 3 , this relationship is in accordance with the study of Aksnes et al. (1985).

The observed mean water exchange between 5 and $15 \mathrm{~m}\left(Q_{\mathrm{vm}}\right)$ during the artificial upwelling periods $\left(\mathrm{A}_{\text {infl }} \leq \mathrm{A}_{\mathrm{o}}\right)$ in the inner part of the Lysefjord was about $240 \mathrm{~m}^{3} \mathrm{~s}^{-1}$, which gives a mean residence time $\left(T_{\mathrm{r}}\right)$ of about $5 \mathrm{~d}$ in the inner $10 \mathrm{~km}^{2}$ of the fjord. The timescale of the phytoplankton response to increased supply of nutrients to the euphotic layer in June 2005 was observed to be 5 to $7 \mathrm{~d}$ (Fig. 7a), which is similar to the mean residence time estimated. The area of influence of increased production based on artificial upwelling is dependent on both the residence time of the phytoplankton layer $\left(T_{\mathrm{r}}\right)$ and the phytoplankton division rate $\left(A_{\mathrm{r}}\right)$. According to Aksnes (1993), the condition for a local or regional effect on new production is dependent upon the ratio $\mathrm{R}=1 /\left(T_{\mathrm{r}} \cdot A_{\mathrm{r}}\right)$. When $R$ is much less than 1 the new production will be local. In the inner $10 \mathrm{~km}^{2}$ of the Lysefjord, $R$ was 0.2 using $A_{\mathrm{r}}=1 \mathrm{~d}^{-1}$. This indicates that most of the artificial upwelling production took place inside the fixed observation area $\mathrm{A}_{\mathrm{o}}$ of $10 \mathrm{~km}^{2}$. Observations of the longitudinal distribution of chl $a$ in the Lysefjord during artificial upwelling in 2004 and 2005 support this assumption.

To estimate the area of influence $\left(\mathrm{A}_{\text {infl }}\right)$ of artificial upwelling in a fjord system we use a combination of Eqs. $\left(4\right.$, where $\mathrm{A}_{o}=\mathrm{A}_{\text {infl, }}$, measured in $\left.\mathrm{km}^{2}\right) \&(6)$ :

$$
\mathrm{A}_{\text {infl }}=\left(\mathrm{CT}_{\text {upw }} / \mathrm{ChlT}_{\text {upw }}\right) \cdot \mathrm{Q}_{\mathrm{v}} /\left(k \cdot H_{\mathrm{a}}\right)
$$

where $H_{\mathrm{a}}$ is the mean thickness (m) of the phytoplankton layer, $\mathrm{CT}_{\text {upw }}$ and $\mathrm{ChlT}_{\text {upw }}$ are the total particulate organic carbon and chl a biomass, respectively, inside $\mathrm{A}_{\text {infl, }} Q_{\mathrm{v}}$ is the water flux out of the phytoplankton layer and $k$ is the is the photosynthetic effectiveness in the phytoplankton layer. $\mathrm{CT}_{\text {upw }} / \mathrm{ChlT}_{\text {upw }}$ is the ratio between total particulate organic carbon and chl a (i.e. $\mathrm{POC} / \mathrm{chl}$ a). It follows that $\mathrm{A}_{\text {infl }}$ is proportional to the mean water exchange $Q_{\mathrm{v}}$ and inversely proportional to $k$ when $H_{\mathrm{a}}$ and POC/chl $a$ are considered as constants. Water flux, $Q_{\mathrm{v}}$ is associated with the residence time of the phytoplankton layer $\left(T_{\mathrm{r}}\right)$ inside $\mathrm{A}_{\text {infl, }}$ and $k$ with the phytoplankton division rate $\left(A_{\mathrm{r}}\right)$ (see previously). The mean chl a concentration $\left(\mathrm{chlm}_{\text {upw }}\right)$ inside the $\mathrm{A}_{\text {infl }}$ is determined by Eqs. (1), (2) \& (7):

$$
\operatorname{chlm}_{\text {upw }}=P_{\text {upw }} \cdot\left[(\mathrm{chl} a / \mathrm{POC}) / Q_{\mathrm{v}}\right]+\left[P_{\mathrm{n}} /\left(k \cdot H_{\mathrm{a}}\right)\right]
$$

In Fig. $10 \mathrm{chlm}_{\text {upw }}$ is calculated as a function of $Q_{\mathrm{v}}$ using $P_{\text {upw }}=6600 \mathrm{~kg} \mathrm{C} \mathrm{d}^{-1}, \mathrm{POC} / \mathrm{chl} a=80, H_{\mathrm{a}}=10 \mathrm{~m}$, $P_{\mathrm{n}}=300 \mathrm{mg} \mathrm{C} \mathrm{m}^{-2} \mathrm{~d}^{-1}$ and $k=18 \mathrm{mg} \mathrm{C} \mathrm{mg} \mathrm{chl} a^{-1} \mathrm{~d}^{-1}$. A mean POC/chl a ratio of $81(n=288)$ was typical for another western Norwegian fjord during the summer 


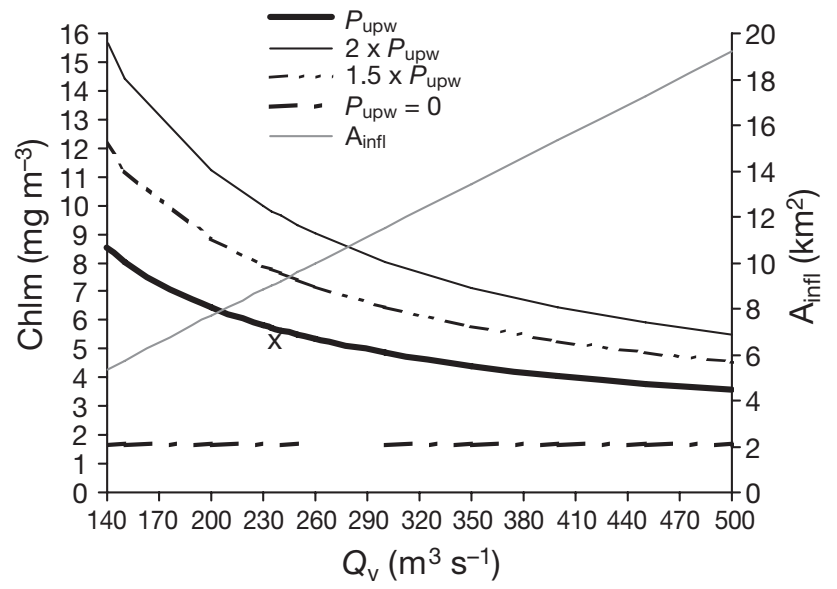

Fig. 10. Calculated area of influence $\left(\mathrm{A}_{\text {infl }}\right)$ and mean chl $a$ (chlm) inside the area of influence as a function of water transport $\left(Q_{\mathrm{v}}\right) . \mathrm{POC} / \mathrm{chl} a=80, \mathrm{H}_{\mathrm{a}}=10 \mathrm{~m}, k=18 \mathrm{mg} \mathrm{C} \mathrm{mg} \mathrm{chl}$ $\mathrm{a}^{-1} \mathrm{~d}^{-1}, \mathrm{P}_{\mathrm{n}}=300 \mathrm{mg} \mathrm{C} \mathrm{m}^{-2} \mathrm{~d}^{-1}$ and $\mathrm{P}_{\mathrm{upw}}=6600 \mathrm{~kg} \mathrm{C} \mathrm{d}^{-1}$. The following cases are shown: $\mathrm{P}_{\text {upw }}=0, \mathrm{P}_{\text {upw }} \times 1, \mathrm{P}_{\mathrm{upw}} \times 1.5$ and $\mathrm{P}_{\text {upw }} \times 2.0$. Mean observed chlm and $Q_{\mathrm{v}}$ (shown by x) during artificial upwelling in 2005 inside $A_{o}=10 \mathrm{~km}^{2}\left(A_{\text {infl }}<A_{o}\right)$

period (Erga et al. 2005). The observed mean chlm upw and $Q_{\mathrm{v}}$ inside $\mathrm{A}_{\mathrm{o}}$ in 2005 were $5.3 \mathrm{mg} \mathrm{m}^{-3}$ and $235 \mathrm{~m}^{3}$ $\mathrm{s}^{-1}$, respectively. As shown in Fig. 10, the observed chlm ${ }_{\text {upw }}$ was well in agreement with the calculated value of $5.7 \mathrm{mg} \mathrm{m}^{-3}$ when $Q_{\mathrm{v}}=235 \mathrm{~m}^{3} \mathrm{~s}^{-1}$. As observed, the calculated $\mathrm{A}_{\text {infl }}$ was less than $10 \mathrm{~km}^{2}$ when $Q_{\mathrm{v}}$ was below $260 \mathrm{~m}^{3} \mathrm{~s}^{-1}$. During natural conditions $\left(P_{\text {upw }}=0\right)$ the mean chl a concentration $\left(\mathrm{chlm}_{\mathrm{n}}\right)$ inside the $\mathrm{A}_{\text {infl }}$ is calculated to be $1.7 \mathrm{mg} \mathrm{m}^{-3}$ (Fig. 10), almost identical to the observed $\operatorname{chlm}_{\mathrm{n}}$ during natural conditions in 2004 and 2005 (1.8 $\left.\mathrm{mg} \mathrm{m}^{-3}\right)$. When the primary production rates due to the artificial upwelling $\left(P_{\text {upw }}\right)$ are increased by factors of 1.5 and 2.0, chlm $_{\text {upw }}$ is increased to 7.8 and $9.8 \mathrm{mg} \mathrm{m}^{-3}$, respectively, when $Q_{\mathrm{v}}=235 \mathrm{~m}^{3}$ $\mathrm{s}^{-1}$. A doubling of $P_{\text {upw }}$ represents a mean daily integrated carbon assimilation of about $1.6 \mathrm{~g} \mathrm{C} \mathrm{m}^{-2} \mathrm{~d}^{-1}$, which is at the same level as the daily integrated carbon assimilation during the main spring bloom in other western Norwegian fjords (Erga \& Heimdal 1984, Erga 1989b, Erga et al. 2005). This level is within the natural variability of the fjord ecosystem and probably a reasonable upper limit of enhanced primary production achieved by artificial upwelling.

The $k$ value of $18 \mathrm{mg} \mathrm{C} \mathrm{mg} \mathrm{chl} a^{-1} \mathrm{~d}^{-1}$ used in our calculations is typical for a chl a maximum at about $10 \mathrm{~m}$ depth during the summer in western Norwegian fjords (S. R. Erga unpubl. data). A shallower intrusion depth $\left(Z_{\mathrm{i}}\right)$ will result in a higher $k$ value, since the $\mathrm{POC} / \mathrm{chl}$ a ratio increases upward in the water column during stratified conditions as light conditions improve (Erga 1989a,b). In periods with persistent low solar irradiance at the surface and/or increased upper layer turbidity, we expect lower $k$ values and, thus, a reduced total primary production rate (PT) (Eq. 6) and increased area of influence $\left(A_{\text {infl }}\right)(E q .7)$. In a comprehensive primary production rate investigation on the Iberian shelf break (northwestern Spain) during periodic upwelling and relaxation events in June through July, $k$ values were found to be within the range 9 to $24 \mathrm{mg} \mathrm{C} \mathrm{mg} \mathrm{chl} \mathrm{a}^{-1} \mathrm{~d}^{-1}$ (primary production rate and chlorophyll concentration, depth-integrated from surface to the base of euphotic zone) (Joint et al. 2002). From their data a mean $k$ value of $16 \mathrm{mg} \mathrm{C} \mathrm{mg} \mathrm{chl} \mathrm{a}^{-1} \mathrm{~d}^{-1}$ can be calculated. However, during a winter upwelling/downwelling sequence in the Ría de Vigo (northwestern Spain), a bloom of Skeletonema costatum revealed $k$ values as high as $45 \mathrm{mg} \mathrm{C}$ $\mathrm{mg} \mathrm{chl} \mathrm{a}^{-1} \mathrm{~d}^{-1}$ (Álvarez-Salgado et al. 2005).

\section{Species succession}

Physical conditions for large-scale blooms of diatoms typically include persistent upwelling regimes (Brown 1992, Taylor \& Haigh 1996, Rutllant \& Montecino 2002, Trainer et al. 2002, Ning et al. 2004, Álvarez-Salgado et al. 2005), and dinoflagellate blooms occur most frequently in stratified waters (Delmas et al. 1993, Reguera et al. 1995, Taylor \& Haigh 1996). Common for many of these upwelling systems is that the growth stimulating response seems to occur towards the end of the upwelling period or beginning of the relaxation period when the water column start to stabilize and nutrients are replenished. In the Lysefjord a modest artificial upwelling was achieved in both 2004 and 2005 , with a mean intrusion depth of 8 to $9 \mathrm{~m}$. It is widely accepted that the coupling between internal biological processes and external physical perturbations plays a key regulatory role in the seasonal succession of phytoplankton (Harris \& Trimbee 1986, Taylor \& Haigh 1996, Teira et al. 2001).

According to the 'intermediate disturbance hypothesis' (IDH), intermediate disturbance or turbulence will lead to maximum species diversity of phytoplankton (see Sommer 1995), while intense disturbances reduce diversity to a few dominant species (Flöder \& Sommer 1999, Huisman et al. 1999). Besides increased production, it was desirable to obtain a dominance of 'healthy' diatoms in our artificial upwelling experiments. One precondition for this is to ensure that sufficient concentrations of 'seed' populations are present in the initial phase of the artificial upwelling at the operational depth of the system (Ishizaka et al. 1983), and that a balance between nutrient supply and the dilution of growing diatoms is obtained. According to Hutchinson (1953), changes in the physical regime on time scales longer than the generation time of the organism, which for phytoplankton is about $1 \pm 0.5 \mathrm{~d}^{-1}$, should prevent 
competitive exclusion. The main advective processes in the inner $10 \mathrm{~km}^{2}$ of the Lysefjord have been shown to operate on a much longer time scale than this (5 to $7 \mathrm{~d}$ ). The retention time should, therefore, be sufficient for a diatom bloom to develop within the main area of artificial upwelling. The artificial upwelling water transport and associated 'turbulence' was insignificant compared with natural water exchange $(12 \%)$. Based on this we do not expect any effects of the artificial upwelling water transport on selection of diatoms.

At the head of the Lysefjord, the daily integral of carbon assimilation with Emiliania huxleyi as the dominant species was no higher than $350 \mathrm{mg} \mathrm{C} \mathrm{m}^{-2} \mathrm{~d}^{-1}$ in June 2005, even if cell concentrations were as high as 10 to $12 \times 10^{6}$ cells $^{-1}$. However, such a low rate of carbon assimilation is not representative of the artificial upwelling period, since it only concerns the initial part when no stimulating effect on primary production rate has been obtained. Previous experience has shown that when natural upwelling in fjords occurs during summer, daily integrals of carbon assimilation of about $1 \mathrm{~g} \mathrm{C} \mathrm{m}^{-2} \mathrm{~d}^{-1}$ could be achieved (Erga 1989b), and that such events may stimulate diatom growth (Aksnes et al. 1985, Paasche \& Erga 1988, Erga 1989a). Silicate is an important competitive factor in this context (Egge \& Aksnes 1992). Our results for the Lysefjord are in accordance with these findings. The dominance of diatoms, however, was higher in 2004 than in 2005, as revealed by their accounting for $90 \%$ and $60 \%$, respectively, of the total biovolume by the end of July. This could be ascribed to the mass occurrence of Emiliania huxleyi in the whole fjord system from mid-June until mid-July 2005, which resulted in unfavourable light conditions due to high concentrations of detached coccoliths in the water column. Typical of such situations are increased scattering to absorption ratios (Frette et al. 2004). It is also interesting to note that by the end of July 2005, Skeletonema sp. was the major contributor to phytoplankton biomass within the area of influence of the artificial upwelling, while outside this area it was almost absent.

In both 2004 and 2005 the diatom stock was greatly reduced during August (Fig. 9). Possible explanations for the diatom breakdown could be a lack of 'seed' diatoms in the influence region or an incidental unbalance between nutrient supply and diatom biomass. From mid-August 2004 the currents within the area of influence increased, which led to higher rates of water exchange. The effect of this may have been a reduced phytoplankton biomass due to dilution. The phytoplankton may, therefore, have adapted to reduced but stable nutrient concentrations, and to less favourable light conditions. Also, diatoms were scarce outside the area of influence both in August 2004 and 2005. Therefore, if the efficiency of the artificial upwelling, as far as diatom growth is concerned, depends on 'seed populations' from outside, lower levels of diatoms are to be expected under such conditions (Ishizaka et al. 1983).

The normal seasonal succession pattern of phytoplankton in fjords of western Norway involves a rising incidence of toxic dinoflagellates in the upper brackish layer from June to September (Dahl et al. 2004, Erga et al. 2005), among which Dinophysis species are most common. Members of the potentially toxic diatom genus Pseudonitzschia (Scholin et al. 2000) are often encountered below the pycnocline in June. This was also the case in the Lysefjord. These 2 genera are also common during the summer in coastal waters throughout the world, and are known to cause problems for the mussel industry (Belin 1993, Reguera et al. 1995, Aune et al. 1996, Taylor \& Haigh 1996, Horner et al. 1997, Ryan et al. 2005, Strohmeier et al. 2005).

When Pseudonitzschia spp. occur in western Norwegian fjords, they are always accompanied by a several other nontoxic diatoms, of which Leptocylindrus spp., Chaetoceros spp. and Skeletonema sp. are the most common (see Erga \& Heimdal 1984, Erga 1989a, Erga \& Skjoldal 1990). Representatives of these genera also made up the largest fraction of diatoms in the Lysefjord during the artificial upwelling period. To date, Pseudonitzschia spp. has not caused any toxicity problems in Norwegian fjords.

In conclusion, the large-scale experiment in the Lysefjord during summers of 2004 and 2005 demonstrated that artificial upwelling of nutrients from deeper water strata approximately tripled mean algae biomass and the estimated primary production rate below the surface layer within an influence area of $10 \mathrm{~km}^{2}$ at the head of the fjord. The concentrations and composition of the upwelling nutrients are identical to those normally encountered during the winter and spring seasons. There were differences in the species composition of the algae within and outside the area of influence, with periodic dominance of diatoms inside the influence area. However, diatom growth seems to be dependent upon 'seed populations' in the adjacent fjord waters. The increase in primary production rate due to artificial upwelling should occur within the natural variability of the fjord ecosystem and be confined to the area of interest. A higher stable level of phytoplankton biomass, dominated by nontoxic species, is likely to increase the fjord's carrying capacity of seston-feeding shellfish and could form the basis of more predictable mussel cultivation in fjords. To investigate this possibility further, a study of the effects of large-scale artificial upwelling on commercial mussel production has now been launched in the Lysefjord. It will also focus more thoroughly on the ecological aspects of artificial upwelling, including implementation of a 3D physical/biological model. 
Acknowledgements. This work was supported by County Council of Rogaland, Norwegian Shellfish Production AS, Lyse Energy AS, Haugalandsrådet and Institute of Marine Research. We thank the crews of RV 'Hans Brattstrøm' and RV 'G. M. Dannevig' for their kind assistance during the cruises. Special thanks go to G. Mykletun for valuable project support, O. M. Gjervik for valuable help during the cruises, and to E. O. Strohmeier for assistance in collecting data between the cruises.

\section{LITERATURE CITED}

Aksnes DL (1993) Sammenfatning av resultater - en vurdering av årsaker. Sluttrapport Prymnesium parvum i Ryfylke. SMR-rapport 9/93, Universitetet i Bergen, Senter for Miljø- og Ressursstudier, Bergen, Norway

Aksnes DL, Magnesen T, Lie U (1985) Nutrient enrichment experiments in plastic cylinders and the implications of enhanced primary production rate in Lindåspollene, western Norway. Sarsia 70:45-58

Aksnes DL, Aure J, Kaartvedt S, Magnesen T, Richard J (1989) Significance of advection for the carrying capacities of fjord populations. Mar Ecol Prog Ser 50:263-274

Álvarez-Salgado XA, Niet-Cid M, Piedracoba S, Crespo BG and others (2005) Origin and fate of a bloom of Skeletonema costatum during a winter upwelling/downwelling sequence in the Ría de Vigo (NW Spain). J Mar Res 63: 1127-1149

Asplin L, Salvanes AG, Kristoffersen JB (1999) Nonlocal wind driven fjord coast advection and its potential effect on plankton fish recruitment. Fish Oceanogr 8:255-263

Aune T, Strand Ø, Aase B, Weidemenn J, Dahl E, Hovgaard P (1996) The Sognefjorden, a possible location for mussel farming? In: Yasumoto $\mathrm{T}$, Oshima Y, Fukuyo Y (eds) Harmful and toxic algal blooms. Intergovernmental Oceanographic Commission of UNESCO, p 73-75

Aure J, Molvær J, Stigebrandt A (1996) Observations of inshore water exchange forced by a fluctuating offshore density field. Mar Pollut Bull 33:112-119

Aure J, Erga SR, Asplin L (2000) Increased biological production in fjords by artificial upwelling. Fisken og Havet (Inst Mar Res Bergen) 11:1-30

Belin C (1993) Distribution of Dinophysis spp. and Alexandrium minutum along French coasts since 1884 and their DSP and PSP toxicity levels. In: Smayda TJ, Shimizu Y (eds) Toxic phytoplankton blooms in the sea. Elsevier, Amsterdam, p 469-474

Berntsen J, Aksnes DL, Foldvik A (2002) Production enhancement by artificial upwelling - a simulation study. Hydrobiologia 484:177-190

Brown PC (1992) Spatial and seasonal variation in chlorophyll distribution in the upper $30 \mathrm{~m}$ of the photic zone in the southern Benguela/Agulhas ecosystem. S Afr J Mar Sci 12:515-525

Dahl E, Aune T, Tangen K, Castberg T, Gustad E and others (2004) Giftalger og algegifter i norske farvann — erfaringer fra de siste fem årene. In: Sjøtun K (ed) Fisken og havet (Inst Mar Res Bergen), p 91-95

Delmas D, Herbland A, Maestrini SY (1993) Do Dinophysis spp. come from the 'open sea' along the French Atlantic coast. In: Smayda TJ, Shimizu Y (eds) Toxic phytoplankton blooms in the sea. Elsevier, Amsterdam, p 489-494

Dugdale RC, Goering JJ (1967) Uptake of new and regenerated forms of nitrogen in primary productivity. Limnol Oceanogr 12:196-206

Egge JK, Aksnes DL (1992) Silicate as regulating nutrient in phytoplankton competition. Mar Ecol Prog Ser 83:281-289

Eilertsen HC, Taasen JP (1984) Investigations on the plankton community of Balsfjorden, northern Norway. The phytoplankton 1976-1978. Environmental factors, dynamics of growth, and primary production rate. Sarsia 69:1-15

Erga SR (1989a) Ecological studies on the phytoplankton of Boknafjorden, western Norway. I. The effect of water exchange processes and environmental factors on temporal and vertical variability of biomass. Sarsia 74:161-176

Erga SR (1989b) Ecological studies on the phytoplankton of Boknafjorden, western Norway. II. Environmental control of photosynthesis. J Plankton Res 11:785-812

Erga SR, Heimdal BR (1984) Ecological studies on the phytoplankton of Korsfjorden, western Norway. The dynamics of a spring bloom seen in relation to hydrographical conditions and light regime. J Plankton Res 6:67-90

Erga SR, Skjoldal HR (1990) Dial variations in photosynthetic activity of summer phytoplankton in Lindåspollene, western Norway. Mar Ecol Prog Ser 65:73-85

Erga SR, Aursland K, Frette Ø, Hamre B and others (2005) UV transmission in Norwegian marine waters: controlling factors and possible effects on primary production rate and vertical distribution of phytoplankton. Mar Ecol Prog Ser 305:79-100

Figueiras FG, Labarta U, Rernández Reiriz MJ (2002) Coastal upwelling, primary production rate and mussel growth in the Rías Baixas of Galicia. Hydrobiologia 484:121-131

Flöder S, Sommer U (1999) Diversity in planktonic communities: an experimental test of the intermediate disturbance hypothesis. Limnol Oceanogr 44:1114-1119

Frette $\varnothing$, Erga SR, Hamre B, Aure J, Stamnes JJ (2004) Seasonal variability in inherent optical properties in a western Norwegian fjord. Sarsia 89:276-291

Harris GP, Trimbee AM (1986) Phytoplankton dynamics of a small reservoir: physical/biological coupling and the time scales of community change. J Plankton Res 8:1011-1025

Horner RA, Garrison DL, Plumley FG (1997) Harmful algal blooms and red tide problems on the U.S. west coast. Limnol Oceanogr 42:1076-1088

Huisman J, van Ostveen P, Weissing FJ (1999) Species dynamics in phytoplankton blooms: incomplete mixing and competition for light. Am Nat 154:46-68

Hutchinson GE (1953) The concept of pattern in ecology. Proc Acad Nat Sci Phila 105:1-11

Ishizaka J, Takahashi M, Ichimura S (1983) Evaluation of coastal upwelling effects on phytoplankton growth by simulated culture experiments. Mar Biol 76:271-278

Joint I, Groom SB, Wollast R, Chou L and others (2002) The response of phytoplankton production to periodic upwelling and relaxation events at the Iberian shelf break: estimates by the ${ }^{14} \mathrm{C}$ method and by satellite remote sensing. J Mar Syst 32: 219-238

Mann KH, Lazier JRN (1996) Dynamics of marine ecosystems: biological-physical interactions in the oceans. Blackwell Science, Malden, MA

McClimans TA, Eidnes G, Aure J (2002) Controlled artificial upwelling in a fjord using submerged fresh water discharge: computer and laboratory simulations. Hydrobiologia 484:191-202

Morikawa T (2001) Stock enhancement of marine living resources in Japan's coastal water. ASEAN-SEAFDEC Millenium Fisheries Exhibition, 11-24 Nov 2001

Ning X, Chai F, Xue H, Cai Y, Liu C, Shi J (2004) Physical-biological oceanographic coupling influencing phytoplankton and primary production rate in the South China Sea. J Geophys Res 109:C10005, doi: 10.1029/2004JC002365 
Olsen YT (2002) MARICULT Research Programme: background, status and main conclusions. Hydrobiologia 484: $1-10$

Paasche E (1988) Pelagic primary production rate in nearshore waters. In: Blackburn TH, Sørensen J (eds) Nitrogen cycling in coastal marine environments. John Wiley \& Sons, Chichester, p 33-57

Paasche E, Erga SR (1988) Phosphorus and nitrogen limitation of phytoplankton in the inner Oslofjord (Norway). Sarsia 73:229-243

Parsons TR, Maita Y, Lalli CM (1992) A manual of chemical and biological methods for sea water analysis. Pergamon Press, New York

Pitcher GC, Calder D (1998) Shellfish mariculture in the Benguela system: phytoplankton availability of food for commercial mussel farms in Saldanha Bay. J Shellfish Res $17: 15-24$

Prasad KS, Lohrenz SE, Redalje DG, Fahlnenstiel GL (1995) Primary production rate in the Gulf of Mexico using a 'remotely-sensed' trophic category approach. Cont Shelf Res 15:1355-1368

Reguera B, Bravo I, Fraga S (1995) Autoecology and some life history stages of Dinophysis acuta Ehrenberg. J Plankton Res 17:999-1015

Riebesell U (1989) Comparison of sinking and sedimentation rate measurements in a diatom winter/spring bloom. Mar Ecol Prog Ser 54:109-119

Rutllant J, Montecino V (2002) Multiscale upwelling forcing cycles and biological response off north-central Chile. Rev Chil Hist Nat 75:217-231

Ryan JP, Chavez FP, Bellingham JG (2005) Physical-biological coupling in Monterey Bay, California: topographic influences on phytoplankton ecology. Mar Ecol Prog Ser 287:23-32

Ryther JH (1969) Photosynthesis and fish production in the sea. Science 166:72-76

Scholin CA, Gulland F, Doucette GJ, Benson S and others (2000) Mortality of sea lions along the central California coast linked to a toxic diatom bloom. Nature 403:80-84

Skjoldal HR, Wassmann P (1986) Sedimentation of particulate organic matter and silicium during summer in Lindåspol-

Editorial responsibility: Howard Browman (Associate Editorin-Chief), Storebø, Norway lene, Western Norway. Mar Ecol Prog Ser 30:49-63

Skjoldal HR, Dalpadado P, Dommasnes A (2004) Food webs and trophic interactions. In: Skjoldal HR, Sætre R, Fernö A, Misund OA, Røttingen I (eds) The Norwegian Sea ecosystem. Tapir Academic Press, Trondheim, p 447-506

Smith WO, Heburn GW, Barber RT, O'Brien JJ (1983) Regulation of phytoplankton communities by physical processes in upwelling ecosystems. J Mar Res 41:539-556

Sommer U (1995) An experimental test of the intermediate disturbance hypothesis using cultures of marine phytoplankton. Limnol Oceanogr 40:1271-1277

Steemann Nielsen E (1952) The use of radio-active carbon $\left({ }^{14} \mathrm{C}\right)$ for measuring organic production in the sea. J Cons Perm Int Expl Mer 18:117-140

Stigebrandt A, Aure J (1988) Observations on plant nutrients in some Norwegian fjords. Sarsia 74:303-307

Strohmeier T, Aure J, Duinker A, Castberg T, Svardal A, Strand $\varnothing$ (2005) Flow reduction, seston depletion, meat content and distribution of diarrhea shellfish toxins in a long-line blue mussel (Mytilus edulis) farm. J Shellfish Res $24: 15-23$

Taylor FJR, Haigh R (1996) Spatial and temporal distribution of microplankton during the summers of 1992-1993 in Barkley Sound, British Columbia, with emphasis on harmful species. Can J Fish Aquat Sci 53:2310-2322

Teira E, Serret P, Fernández E (2001) Phytoplankton sizestructure, particulate and dissolved organic carbon production and oxygen fluxes through microbial communities in the NW Iberian coastal transition zone. Mar Ecol Prog Ser 219:65-83

Trainer VL, Hickey BM, Horner RA (2002) Biological and physical dynamics of domoic acid production off the Washington coast. Limnol Oceanogr 47:1438-1446

Utermöhl H (1931) Neue Wege in der quantitativen Erfassung des Planktons. (Mit besonderer Berücksichtigung des Ultraplanktons). Verh Int Verein Theor Angew Limnol 5: 567-596

Wassmann P (1990) Relationship between primary and export production in the boreal coastal zone of the North Atlantic. Limnol Oceanogr 35:464-471

Submitted: January 12, 2007; Accepted: June 30, 2007 Proofs received from author(s): November 28, 2007 